\title{
Subjective Financial Distress in the Formation of Consumer Confidence: Evidence from Novel Household Data*
}

\author{
Tufan Ekici**
}

Middle East Technical University Northern Cyprus Campus

\begin{abstract}
In this paper we analyze the psychological and socio-economic determinants of consumer confidence using household level data. Even though the aggregate Consumer Confidence Index (CCI) is widely utilized by policy-makers in developed countries, there is still some concern that the index does not contain any information that is not already available in other economic measures. Our paper has two main objectives: (1) to analyze the individual questions in the index and to identify the correlates of consumer confidence by using micro level data, and (2) to study a new variable, subjective financial distress (SFD), that captures the 'mood' of the consumers that might be useful in explaining consumer confidence. SFD measures how much stress consumers have about their current debt obligations and how concerned they are about the inability to pay off the debt in the future. We consistently find that SFD is correlated with overall $\mathrm{CCI}$ and its individual questions. Higher distress is found to increase the probability of reporting negative sentiment, even in the presence of many other economic and demographic variables. This result should be seen as evidence that there are psychological factors in the formation of consumer confidence, and hence that using a consumer confidence index, along with other economic variables, to forecast economic activity is justified. These results also indicate that consumer confidence reflects more than just the information consumers have about economic activity.
\end{abstract}

Keywords: subjective financial distress, consumer confidence index, future expectations.

JEL Classifications: D12, D84

* An earlier draft of this paper was presented at ICABE 2010 conference. The author would like to thank Lucia F. Dunn, Serkan Özbeklik and two anonymous referees for their helpful comments and suggestions. All remaining errors are my own.

** Tufan Ekici is an Assistant Professor in the Department of Economics at the Middle East Technical University, Northern Cyprus Campus, Kalkanli, Güzelyurt, Mersin 10, Turkey. E-mail: ekici@metu.edu.tr. 


\section{Tüketici Güven Endeksi'nin Oluşumunda Sübjektif Mali Sıkıntı'nın Rolü: Orijinal Hane Halkı Verisinden Elde Edilen Bulgular}

\section{Özet}

Bu makalede hane halk1 verileri kullanılarak tüketici güvenini etkileyen psikolojik ve sosyal-ekonomik faktörler araştırılmıştır. Makro bazdaki Tüketici Güven Endeksi (TGE) gelişmiş ülkelerde sıkça kullanılmakla birlikte, diğer iktisadi endekslerde rastlanmayan kendine özgü bilgiler içermediği konusundaki kaygılar hakkındaki tartışmalar da sürmektedir. Mevcut makalenin iki ana hedefi vardır: (1) Mikro verileri kullanarak endeksin içindeki soruları ayrı ayrı analiz edip tüketici güveni ile korelasyonu olan sosyal ve ekonomik değişkenleri tespit etmek, ve (2) daha önce bu bağlamda kullanılmamış ve tüketicinin mevcut mali borçları ve bunları ileride ödeyememeleri durumundaki psikolojik hislerini ölçen Sübjektif Mali Sıkıntı (SFS) isimli yeni bir değişkenin etkisini araştırmak. Yapılan analizler sonunda SFS ile TGE arasında tutarlı bir şekilde yüksek derecede korelasyon olduğu ortaya çıkmıştır. Diğer birçok sosyal ve ekonomik değişkenlerin de kontrol edilmelerine rağmen, daha yükssek stresli olan tüketicilerin daha az güven hissettikleri ortaya çıkmıştır. Bu sonuç tüketicilerin ekonomik durum hakkında görüş oluşturduklarında mevcut genel bilgilerden de öte kendi psikolojik eğilimlerine de başvurduklarını göstermektedir.

Anahtar Kelimeler: sübjektif mali sıkıntı, tüketici güven endeksi, gelecek tahminleri.

JEL Sinıflamasi: D12, D84

$\mathrm{T}$

The Index of Consumer Sentiment (ICS), released by the University of Michigan, and the Consumer Confidence Index (CCI), released by the Conference Board, are both widely utilized by policy-makers in the US, and their components are among the leading indicators for the US economy. ${ }^{[1]}$ One of the attractive features of these indices is their immediate availability: they are released much earlier than other aggregate information on the economy such as aggregate consumption and income. The importance of the ICS in predicting consumption growth has been well documented at both macro and micro levels for the US (Carroll et. al., 1995; Eppright et. al., 1998; Howrey, 2001; Ludvigson, 2004; Souleles, 2004) and some other industrialized countries (Acemoglu and Scott (1994) for the United Kingdom; Goh (2003) for New Zealand; Kwan and Cotsomitis (2006) for Canada; and Malgarini and Margani (2007) for Italy). There is also evidence that consumer confidence is an important determinant of consumer behavior in the US credit card market (Ekici, 2006). Overall, consumer confidence measures play very important roles in predicting both macroeconomic and microeconomic behavior. This calls for further attention to the factors that might influ-

[1] ICS and CCI are both measured using five similar questions, but each set of questions is worded differently. Bram and Ludvigson (1998) compare both surveys and find that CCI has weaker forecasting power for consumption. Nevertheless, CCI is still used by many economists to forecast economic activity in the US. 
ence the formation of consumer confidence. There are, however, very few studies that directly concentrate on this issue.

The usefulness of consumer confidence measures to predict future economic activities, mainly aggregate consumption, has been well documented in the literature. But disagreement arises as to the reasons behind its usefulness. On the one side, researchers such as Barsky and Sims (2012) and Beaudry and Portier (2006) support the "information view," believing that consumer confidence measures contain information about the current and future states of the economy.

Conversely, Hall (1993) and Blanchard (1993) use the "animal spirits" explanation. Blanchard (1993: 247) states that "consumption shocks reflect in part movements in consumption not due to changes in expectations of future income. Reasons may change from increasing prudence to changes in intertemporal preferences, to sudden realizations of past over-borrowing, panic, and so on." In this paper we have evidence to support the latter explanation.

The aim of this paper is modest, but we believe that it will contribute to the literature on the significance of the consumer confidence index in a significant and meaningful way. First, we will explore the socioeconomic correlates of consumer confidence by using novel micro-level data. Most of the earlier studies used aggregate data on consumer confidence. Since CCI and ICS are both constructed by using individual responses from the surveyed households, using aggregate data may mask the true behavioral aspects of those responses. Previous studies found heterogeneous forecast errors in consumer sentiment (Souleles, 2004). Therefore, it is imperative to match the confidence of households with the potential household-level variables that might influence it.

We also introduce a new non-economic variable that is a potentially important correlate of consumer confidence. The new variable measures consumers' subjective financial distress (SFD), and is constructed by using individual responses to several survey questions in our data set. This variable is utilized to test if CCI includes any additional information other than objective financial conditions of the households. The phrase "financial distress" is usually used in macroeconomics to reflect a household's objective debt burden, such as total revolving credit or the ratio of amount borrowed to household income. However, we are also interested in psychological factors such as subjective debt burdens, so we focus on how respondents feel about their debt levels. In other words, we differentiate between subjective and objective financial distress. This allows us to control for psychological factors that might be important correlates of consumer confidence.

The paper is organized as follows. In the next section we review the relevant literature on consumer confidence and debt stress. Section 3 introduces the dataset and presents some descriptive statistics on our main variables. Section 4 introduces our econometric methodology and gives the results of the estimation. Finally, we discuss the results and conclude the paper in Sections 5 and 6, respectively. 


\section{Literature Review}

As noted earlier, there has been relatively little research on the correlates of consumer confidence. One of the earliest studies on this topic was carried out by Acemoğlu and Scott (1994). They find that unemployment rate, inflation rate, change in housing wealth, and lagged confidence are correlated with aggregate consumer confidence. Since then, other researchers have focused on other variables such as the real interest rate and public debt (de Mendonca, 2009), the stock market (Lopez and Durre, 2003; Golinelli and Parigi, 2003; Jos Jansen and Nahuis, 2003), and news coverage (Alsem et. al., 2008). One common feature of all of these articles is their reliance on aggregate macro data. ${ }^{[2]}$ Although we are not denying the value of using macro variables in such an analysis, we believe that aggregate data cannot accurately capture the psychological influences on consumer sentiment. This is mainly due to the fact that the financial distress of the households are affected by demographic variables as well as the type of debt (Dunn and Mirzaie, 2012). Therefore aggregating heterogeneous consumers with varying distress levels into aggregate data could be problematic.

Since the pioneering work of Katona $(1951,1975)$, economists have argued over whether consumer sentiment reflects the subjective state of mind of consumers or is merely a reflection of the information consumers have about the overall economic conditions. Recent literature (Souleles, 2004; Carroll, 2007) shows that expectations of economic variables could be influenced by socioeconomic and demographic characteristics of the surveyed households. Blanchard (1993) and Lopez and Durre (2003) note the importance of "psychological factors" in predicting consumer confidence, but neither study is able to use a variable to capture such effects. In this paper we introduce a new variable, namely the level of stress from having debt, which we believe captures one aspect of these factors. Throop (1992) shows that financial distress (as proxied by the aggregate financial assets of all the households) and household debt are no longer significant predictors of aggregate consumer sentiment, after accounting for other control variables, such as changes in stock prices, changes in unemployment rate, and interest rates. These results, however, are also obtained by using aggregate level data, and the measured level of distress is objective rather than subjective. We use micro-level data on financial distress which enable us to assess the impact, if any, of non-economic individual specific factors that other researchers were unable to analyze. ${ }^{[3]}$

The question of how best to capture subjective financial distress is also important. There aren't many household surveys that contain questions on this topic. The Ger-

[2] There are several articles that analyze the correlates of a given household's future income expectations by using micro data. These expectations are part of the consumer confidence index, and we also tackle them in our analysis. For a review of these articles please refer to Ramos and Schluter (2006). Nonetheless, none of these articles use financial distress as an explanatory variable in their analysis.

[3] Subjective financial distress has been found to be correlated with health (Drentea and Lavrakas, 2000) and anxiety (Drentea, 2000). Prolonged financial distress is also found to be associated with drinking problems, decreased selfesteem, marital stress, depression, and workplace absenteeism (see Kim et. al., 2006 for a review of this literature). 
man Socio-Economic Panel (GSOEP) and the British Household Panel Study (BHPS) are the two largest datasets that include information on subjective household financial distress. For example, the GSOEP asks the following question about the respondent's self-assessed debt burden: "Does repaying these loans (consumer loans) place a major burden on your household, a minor burden, or no burden at all?" The corresponding item in the BHPS queries whether the household's debt repayments constitute "a heavy burden, somewhat of a burden or not a problem." Some researchers have analyzed the socioeconomic correlates of subjective financial distress using these two datasets, among other sources (Brown et. al., 2005; Del Rio and Young, 2005; Lenton and Mosley, 2008; Keese, 2012; and Dunn and Mirzae, 2012). The common result in all of these studies is the fact that subjective financial distress is affected by socio-demographic variables and is thus not homogenous among consumers. In other words, two consumers with the exact same amount of household debt can potentially have different psychological stress levels, which will influence their confidence about the economy. Thus, it is necessary to analyze consumer confidence using household level variables, including both subjective and objective financial distress as controls.

To the best of our knowledge, the association between subjective financial distress and consumer confidence at the household level has not been explored before. Given the increased dependence of U.S. consumers on debt, especially on credit card debt, ${ }^{[4]}$ it is natural to ask if stress from indebtedness has any effect on consumers' economic decisions through their confidence. Using household level data enables us to control for consumer heterogeneity, which was not possible for previous researchers. We introduce the dataset in the next section.

\section{Data and Descriptive Statistics}

The data used in this paper comes from the Ohio Economic Survey (OES), a monthly survey conducted between November 1996 and April 2002 by the Center for Survey Research at Ohio State University. Every month, different households were interviewed by phone. The survey collected information on consumer confidence, credit card use, debt stress, and other demographic items. The collection of data on different variables started at different times, so we use only the data from February 1998 onwards to make sure that we have information on all the variables needed for this study. The final sample has 16771 observations. The data is unique for our purposes as it is the only known survey that contains information on consumers' subjective stress levels related to their debt holding, along with complete measures of consumer confidence. ${ }^{[5]}$

\footnotetext{
[4] For a review of literature on credit card debt, see Dunn et. al. (2006).

[5] Although OES is a statewide survey, the socioeconomic characteristics of the state of Ohio are very close to the national averages. Thus we believe that our sample is a representative sample of the US population. For more information on OES, see Dunn et. al. (2006). Another data source that has the same financial distress questions is Consumer Finance Monthly (CFM) which is a nationwide survey, however CFM does not have all of the consumer confidence questions (except current income realization).
} 


\section{Dependent Variables}

The questions related to consumer confidence are the same questions that have been asked by the University of Michigan Survey (ICS) since the 1970s. Dunn and Mirzae (2006: 349) show that the Ohio Consumer Confidence Index (OCCI) leads the ICS and "predicts consumption by reflecting private information on underlying economic conditions rather than by being a cause of consumption pattern." The time series trend of the OCCI, along with that of the ICS, is provided in the Appendix. Given the similarity between the state level and national index, we believe that we can potentially generalize our results for the U.S. population. The questions asked in the survey and the response options (in parentheses) are given below.

- A1. Would you say that you and your family living there are better off or worse off financially than you were a year ago? (Better off, Same, Worse off)

- A2. Now looking ahead, do you think a year from now you (and your family) will be better off financially, or worse off, or just about the same as now? (Better off, Same, Worse off)

- A3. Now, turning to business conditions in the country as a whole, do you think that during the next 12 months we'll have good times financially, or bad times, or what? (Good times, good times with qualification, Uncertain, Bad times with qualification, Bad times)

- A4. Looking ahead, in the country as a whole, do you think we'll have continuous good times during the next five years, or that we will have periods of widespread unemployment or depression, or what? (Good times, good times with qualification, Uncertain, Bad times with qualification, Bad times)

- A5. Generally speaking, do you think now is a good or bad time for people to buy major household items? (Good time, Uncertain, Bad time)

We use different variations of the OCCI as dependent variables. First we take the arithmetic average of all the five questions for each respondent and create the Consumer Confidence Index (CCI) ${ }^{[6]}$ This variable basically includes all the information available in the aggregate index. Then we only focus on the three questions that ask for perspectives on the future (A2, A3 and A4), and take the average of those three questions. We name this variable as the Index of Consumer Expectations (ICE), which is consistent with Michigan's definition. Finally, we use each question as a separate dependent variable, in order to see if different factors are correlated differently with individual questions.

[6] We assign values of 1,2 and 3 to the responses of the questions A1, A2 and A5 where higher numbers indicate better outcomes. For A3 and A4, we collapse the two positive and negative categories and use the three category scale (good times, uncertain, bad times) where higher numbers indicate better states. 


\section{Main Independent Variable}

Our main independent variable is subjective financial distress. In this study we use a more detailed set of information that captures SFD. There are four questions that have been asked in the OES regularly since February 1998. These questions are intended to capture the stress and discomfort from the current debt holding of the households, as well as the respondent's concern about the inability to pay off debt in the longer term (Dunn and Mirzaie, 2012). The questions and response options are given below, with the corresponding variable names (used in the estimation section) in brackets. The SFD is simply the average of the four questions (B1 to B4) where higher numbers indicate more financial distress.

- B1. How often do you worry about the total amount you owe in overall debt? (All of the time, most of the time, some of the time, hardly ever, not at all) [WORRYDEBT]

- B2. How much stress does the overall debt you have cause to you? (a great deal of stress, quite a bit, somewhat, not very much, no stress at all) [STRESSDEBT]

- B3. How much of a problem in the next five years will the total debt you have taken on be for you? (an extreme problem, a large one, medium, small, no problem at all) [WORRYNOW]

- B4. How concerned are you that you will never be able to pay off these debts? (very concerned, quite concerned, somewhat concerned, not very concerned, not at all concerned) [WORRYALWAYS]

We believe that these questions capture a unique consumer characteristic that is different than overall consumer confidence. Financial distress measures definitely capture the objective financial condition of the households. In fact researchers using macro data have used total revolving credit as a measure of financial distress. However as we described in the previous section, at the household level different demographic variables are found to be correlated with subjective distress. The reason is simple: not everyone can handle financial pressure equally. This is not due to the amount of debt but rather due to the ability to handle such conditions which includes emotional and psychological dimensions. These questions are intended to capture such dimensions. And if SFD is found to be correlated with consumer confidence, then we will be able to claim that consumer confidence is more than just information on objective financial conditions.

Table 1 shows the distribution of SFD across different debt-income deciles. As can be seen from the table, higher unsecured debt burden is associated with higher subjective distress which is to be expected. However, the standard deviations of SFD across different deciles are very high which indicates that the distribution of distress is not homogeneous across different debt burdens. Thus SFD not only measures objective financial conditions but also includes subjective psychological factors. 
Table 1

Distribution of SFD across Debt-Income Deciles

\begin{tabular}{c|c|c}
\hline & \multicolumn{2}{|c}{ SFD } \\
\hline $\begin{array}{c}\text { Debt-Income } \\
\text { Deciles }\end{array}$ & Mean & $\begin{array}{c}\text { Standard } \\
\text { Deviation }\end{array}$ \\
\hline 0 & 2,04 & 0,96 \\
\hline 1 & 1,82 & 0,75 \\
\hline 2 & 1,91 & 0,80 \\
\hline 3 & 2,01 & 0,78 \\
\hline 4 & 2,09 & 0,85 \\
\hline 5 & 2,11 & 0,83 \\
\hline 6 & 2,20 & 0,88 \\
\hline 7 & 2,33 & 0,87 \\
\hline 8 & 2,40 & 0,86 \\
\hline 9 & 2,54 & 0,92 \\
\hline 10 & 2,88 & 0,99 \\
\hline
\end{tabular}

*0 refers to those who said they have absolutely no unsecured debt

\section{Other Independent Variables}

Other economics-related independent variables include views on past and future inflation, objective debt burden, and household income. The respondents are allowed to provide an exact figure on what they think the past year's inflation rate was, and what it will be in the next 12 months. This allows us to construct variables that measure the respondent's own views on past and future inflation. Objective debt burden is created by taking the ratio of total unsecured debt (credit card debt) to total household income, and then we create three dummy variables that correspond to the bottom, middle and top third of the total sample. Finally, total household income is captured by four dummy variables that correspond to different quartiles in our sample. ${ }^{[7]}$

We also include two other variables that capture media exposure as potential explanatory variables, in order to be consistent with the previous literature. Previous research has shown that there is a strong association between the way news is reported and aggregate consumer confidence, and that the correlation is even stronger when the news is more pessimistic (Alsem et. al., 2008; Hollanders and Vliegenthart, 2011; Casey and Owen, 2013). We have information on the number of times the respondent read a newspaper this week and the average number of hours the respondent watches television each day. We realize that these variables are not exactly great measures of media coverage on economic activities, but they are used as proxy variables.

[7] We also used continuous measures of debt and income measures. The results were qualitatively the same. 
Table 2

\section{Definition and Percentages of Other Explanatory Variables}

\begin{tabular}{|c|c|c|}
\hline Variable & $\begin{array}{l}\text { Mean } \\
\text { (Standard } \\
\text { Error) }\end{array}$ & Explanation \\
\hline $\begin{array}{l}\text { Current } \\
\text { Inflation* }\end{array}$ & $\begin{array}{l}5.29 \\
(8.89)\end{array}$ & About what percent did the overall prices change in the last 12 months \\
\hline $\begin{array}{l}\text { Future } \\
\text { Inflation }\end{array}$ & $\begin{array}{l}4.41 \\
(7.31)\end{array}$ & $\begin{array}{l}\text { About what percent do you expect the prices to change in the next } 12 \\
\text { months }\end{array}$ \\
\hline Debt Burden 1 & 41.81 & $\begin{array}{l}\text { Credit card debt to household income between } 0 \text { and } 0.0015 \text { (bottom third } \\
\text { of the sample) }\end{array}$ \\
\hline Debt Burden 2 & 20.83 & $\begin{array}{l}\text { Credit card debt to household income between } 0.0015 \text { and } 0.032 \\
\text { (middle third of the sample) }\end{array}$ \\
\hline Debt Burden 3 & 20.91 & $\begin{array}{l}\text { Credit card debt to household income more than } 0.032 \\
\text { (top third of the sample) }\end{array}$ \\
\hline Homeowner & 75.41 & Own a home \\
\hline Employed & 61.88 & Currently employed \\
\hline Income 1 & 36.84 & Household Income less than $\$ 25000$ \\
\hline Income 2 & 19.49 & Household Income between $\$ 25000$ and $\$ 40000$ \\
\hline Income 3 & 22.76 & Household Income between $\$ 40000$ and $\$ 65000$ \\
\hline Income 4 & 20.90 & Household Income more than $\$ 65000$ \\
\hline Education 1 & 9.51 & Highest grade completed less than high school \\
\hline Education 2 & 35.03 & Highest grade completed High School Diploma \\
\hline Education 3 & 44.16 & Highest grade completed more than High school less than college \\
\hline Education 4 & 11.30 & Highest grade completed college diploma or more \\
\hline Age 1 & 11.52 & Respondent's age less than equal to 25 \\
\hline Age 2 & 18.59 & Respondent's age between 25 and 35 \\
\hline Age 3 & 22.94 & Respondent's age between 26 and 45 \\
\hline Age 4 & 18.68 & Respondent's age between 46 and 55 \\
\hline Age 5 & 12.15 & Respondent's age between 56 and 65 \\
\hline Age 6 & 16.11 & Respondent's age more than 65 \\
\hline Male & 41.07 & Respondent is Male \\
\hline White & 87.70 & Respondent is white \\
\hline Paper 1 & 12.38 & Respondent read no newspaper last week \\
\hline Paper 2 & 35.42 & Respondent read newspaper between 1 and 5 days last week \\
\hline Paper 3 & 52.03 & Respondent read newspaper 6 days or more last week \\
\hline Tv 1 & 9.74 & On average the respondent watches no TV each day \\
\hline $\operatorname{Tv} 2$ & 66.61 & On average the respondent watches TV up to 4 hours each day \\
\hline Tv 3 & 23.65 & On average the respondent watches more than 4 hours of TV each day \\
\hline September 11 & 27.54 & The interview is conducted after September 11, 2001 \\
\hline
\end{tabular}


Finally, we use a dummy variable indicating whether the survey was conducted after September 2001. Consumer confidence plummeted right after the 9/11 terrorist attacks on the U.S., and since our survey ended at the beginning of 2002, we wanted to control for this external shock to the economy. Variables indicating employment status, home ownership, age, education, gender, and race are also used to control for individual heterogeneity among the respondents. We also include time dummies, both monthly and yearly, to control for seasonal changes in confidence and aggregate conditions in the whole economy. The complete list of the independent variables is given in Table 2 .

\section{Estimation Methodology and Results}

\section{Estimation Methodology}

To analyze the relationship between subjective financial distress and consumer confidence, we use Ordinary Least Squares (OLS) and ordered logistic regressions. We first create two individual-level confidence indices, taking the averages of all five questions (consumer confidence index, CCI) and the average of only the three of the expectations questions (index of consumer expectations, ICE). Since these variables are continuous, as a first step in analyzing the correlates of consumer confidence we use OLS.

In the second step, we take each question and analyze the correlates separately. Since the responses are ordered in nature, we use ordered logistic regression for each consumer confidence question. Better states are coded as $\left(\mathrm{Y}_{\mathrm{i}}=1\right)$, worse states are coded as $\left(\mathrm{Y}_{\mathrm{i}}=-1\right)$, and the same states are coded as $\left(\mathrm{Y}_{\mathrm{i}}=0\right) \cdot{ }^{[8]}$ The following log-likelihood is maximized to obtain the parameters of interest:

$$
\begin{aligned}
L & =\sum_{i=1}^{N} 1\left[Y_{i}=-1\right] \log \left[\Lambda\left(\alpha_{1}-X_{i} \beta\right)\right]+\sum_{i=1}^{N} 1\left[Y_{i}=0\right] \log \left[\Lambda\left(\alpha_{2}-X_{i} \beta\right)\right] \\
& +\sum_{i=1}^{N} 1\left[Y_{i}=1\right] \log \left[\Lambda\left(\alpha_{3}-X_{i} \beta\right)\right]
\end{aligned}
$$

where $\Lambda($.$) is the cumulative logistic distribution function, \alpha_{j}$ is the threshold parameter for state $j, X_{\mathrm{i}}$ is the vector of variables used in regressions including financial distress variables, and $\beta$ is the corresponding vector of parameters. Then, the probability of observation $i$ to be in state $j$ can be written as

$$
\operatorname{Pr}\left(y_{i}=j\right)=\Lambda\left(\hat{\alpha}_{j}-X_{i} \hat{\beta}\right)-\Lambda\left(\hat{\alpha}_{j-1}-X_{i} \hat{\beta}\right)
$$

Finally, we calculate the marginal effects of each variable in vector $X$ for all three states, as

$$
\frac{\partial \operatorname{Pr}\left(y_{i}=j\right)}{\partial X_{i}}=\hat{\beta} \lambda\left(\hat{\alpha}_{j}-X_{i} \hat{\beta}\right)-\hat{\beta} \lambda\left(\hat{\alpha}_{j-1}-X_{i} \hat{\beta}\right), \quad j=-1,0,1
$$

where $\lambda($.$) is logistic probability density function.$

${ }^{[8]}$ For the two questions that have five categories, we collapse the top and bottom two responses into the same category. 
We run separate estimations for each of the consumer confidence questions, including each of the stress variables, one at a time. Therefore, for each dependent variable we will have four different estimations, and include all the variables in Table 2 along with the debt stress variables. However we do not use current inflation and future inflation in the same model. We will use current inflation to trace sentiment on current income and buying conditions, and for the rest of the dependent variables we will use future inflation among the explanatory variables. The intuition of this practice is as follows: if a consumer is asked about his/her perceptions of the current economic conditions, he/she is more likely to take into account the current prices and how they compare with prices a year ago. On the other hand, for expectations on future economic conditions, future prices are more likely to have an impact on consumer behavior.

There are some potential problems that may be encountered with the estimations. As we will explain below, we use several independent variables in our models and these variables might be correlated with each other (multicollinearity) which would bias our estimators. Also these variables could potentially suffer from measurement error. Some of the variables such as income and household debt are sometimes underreported in the surveys. Finally the distributional assumptions of the error term in the ordered choice model can potentially influence the structure of the model and semiparametric approaches could be more applicable although more complicated (Stewart, 2005). For our purposes logit assumption seems reasonable since we are only interested in qualitative relationship between our variables of interest. Nevertheless we carry on with our OLS and ordered logit estimations keeping these caveats in mind.

\section{Results}

Socioeconomic variables and consumer confidence. We first present the results on the relationship between the main socioeconomic variables and consumer confidence. We have various models for both CCI and ICE where we add independent variables. Models (1) and (5) in Table 3 show how basic demographic variables are correlated with CCI and ICE respectively. We see that more educated, younger respondents who read more newspaper and watch TV have more confidence than their counterparts. These results indicate that consumers are not homogeneous and different demographics could influence consumer confidence. Thus aggregating heterogeneous consumers when creating aggregate indices could suppress the true behavioral aspects behind the formation of consumer confidence.

Models (2) and (6) take into account, in addition to the demographic variables, some of the economic variables such as household income, homeownership and employment status, and credit card debt burden. We immediately see that higher household income is associated with higher consumer confidence. Debt burden is found to be negatively associated with consumer confidence but it is insignificant for the expectations index (Model 6). Finally employed individuals have more confidence than unemployed counterparts. All these indicate that financially more secure households are also more optimistic about the economic conditions. Homeownership however is found to be very mildly or not at all correlated with confidence in these models. 
Table 3

\section{OLS results of SFD on Consumer Confidence Index (CCI) and Index of Consumer Expectations (ICE)}

\begin{tabular}{|c|c|c|c|c|c|c|c|c|}
\hline & \multicolumn{4}{|c|}{ Consumer Confidence Index } & \multicolumn{4}{|c|}{ Index of Consumer Expectations } \\
\hline & Model 1 & Model 2 & Model 3 & Model 4 & Model 5 & Model 6 & Model 7 & Model 8 \\
\hline Education 2 & $\begin{array}{l}0.083 * * * \\
(0.015)\end{array}$ & $\begin{array}{l}0.068^{* * *} \\
(0.015)\end{array}$ & $\begin{array}{l}0.067 * * * \\
(0.015)\end{array}$ & $\begin{array}{l}0.042 * * * \\
(0.015)\end{array}$ & $\begin{array}{l}0.073^{* * *} \\
(0.018)\end{array}$ & $\begin{array}{l}0.072 * * * \\
(0.019)\end{array}$ & $\begin{array}{l}0.070 * * * \\
(0.019)\end{array}$ & $\begin{array}{l}0.050 * * \\
(0.019)\end{array}$ \\
\hline Education 3 & $\begin{array}{l}0.155^{* * * *} \\
(0.017)\end{array}$ & $\begin{array}{l}0.128 * * * \\
(0.017)\end{array}$ & $\begin{array}{l}0.128 * * * \\
(0.016)\end{array}$ & $\begin{array}{l}0.098 * * * \\
(0.015)\end{array}$ & $\begin{array}{l}0.163 * * * \\
(0.020)\end{array}$ & $\begin{array}{l}0.152 * * * \\
(0.021)\end{array}$ & $\begin{array}{l}0.150 * * * \\
(0.021)\end{array}$ & $\begin{array}{l}0.126^{* * *} \\
(0.021)\end{array}$ \\
\hline Education 4 & $\begin{array}{l}0.209 * * * \\
(0.016)\end{array}$ & $\begin{array}{l}0.166^{* * * *} \\
(0.016)\end{array}$ & $\begin{array}{l}0.167 * * * \\
(0.016)\end{array}$ & $\begin{array}{l}0.129 * * * \\
(0.015)\end{array}$ & $\begin{array}{l}0.221^{* * * *} \\
(0.019)\end{array}$ & $\begin{array}{l}0.196^{* * * *} \\
(0.020)\end{array}$ & $\begin{array}{l}0.197 * * * \\
(0.020)\end{array}$ & $\begin{array}{l}0.167 * * * \\
(0.020)\end{array}$ \\
\hline Age 1 & $\begin{array}{l}0.072 * * * \\
(0.013)\end{array}$ & $\begin{array}{l}0.093 * * * \\
(0.013)\end{array}$ & $\begin{array}{l}0.099 * * * \\
(0.013)\end{array}$ & $\begin{array}{l}0.082^{* * *} \\
(0.013)\end{array}$ & $\begin{array}{l}0.070 * * * \\
(0.014)\end{array}$ & $\begin{array}{l}0.075^{* * *} \\
(0.016)\end{array}$ & $\begin{array}{l}0.080 * * * \\
(0.015)\end{array}$ & $\begin{array}{l}0.067 * * * \\
(0.015)\end{array}$ \\
\hline Age 2 & $\begin{array}{l}0.066^{* * * *} \\
(0.009)\end{array}$ & $\begin{array}{l}0.072 * * * \\
(0.010)\end{array}$ & $\begin{array}{l}0.069 * * * \\
(0.009)\end{array}$ & $\begin{array}{l}0.071 * * * \\
(0.009)\end{array}$ & $\begin{array}{l}0.055^{* * *} \\
(0.011)\end{array}$ & $\begin{array}{l}0.058 * * * \\
(0.011)\end{array}$ & $\begin{array}{l}0.055^{* * *} \\
(0.011)\end{array}$ & $\begin{array}{l}0.057 * * * \\
(0.011)\end{array}$ \\
\hline Age 4 & $\begin{array}{l}-0.038^{* * * *} \\
(0.009)\end{array}$ & $\begin{array}{l}-0.035^{* * *} \\
(0.009)\end{array}$ & $\begin{array}{l}-0.037 * * * \\
(0.009)\end{array}$ & $\begin{array}{l}-0.053 * * * \\
(0.009)\end{array}$ & $\begin{array}{l}-0.033^{* * *} \\
(0.012)\end{array}$ & $\begin{array}{l}-0.030 * * \\
(0.012)\end{array}$ & $\begin{array}{l}-0.033^{* * *} \\
(0.012)\end{array}$ & $\begin{array}{l}-0.046^{* * * *} \\
(0.012)\end{array}$ \\
\hline Age 5 & $\begin{array}{l}-0.084 * * * \\
(0.012)\end{array}$ & $\begin{array}{l}-0.055^{* * *} \\
(0.013)\end{array}$ & $\begin{array}{l}-0.049 * * * \\
(0.012)\end{array}$ & $\begin{array}{l}-0.108 * * * \\
(0.012)\end{array}$ & $\begin{array}{l}-0.066^{* * *} \\
(0.015)\end{array}$ & $\begin{array}{l}-0.045^{* * *} \\
(0.015)\end{array}$ & $\begin{array}{l}-0.041 * * * \\
(0.014)\end{array}$ & $\begin{array}{l}-0.087 * * * \\
(0.014)\end{array}$ \\
\hline Age 6 & $\begin{array}{l}-0.149 * * * \\
(0.015)\end{array}$ & $\begin{array}{l}-0.067 * * * \\
(0.015)\end{array}$ & $\begin{array}{l}-0.058^{* * *} \\
(0.014)\end{array}$ & $\begin{array}{l}-0.146^{* * *} \\
(0.015)\end{array}$ & $\begin{array}{l}-0.113^{* * *} \\
(0.018)\end{array}$ & $\begin{array}{l}-0.060 * * * \\
(0.019)\end{array}$ & $\begin{array}{l}-0.051^{* * *} \\
(0.018)\end{array}$ & $\begin{array}{l}-0.120 * * * \\
(0.019)\end{array}$ \\
\hline Paper2 & $\begin{array}{l}0.041 * * * \\
(0.010)\end{array}$ & $\begin{array}{l}0.033^{* * *} \\
(0.010)\end{array}$ & $\begin{array}{l}0.027 * * * \\
(0.010)\end{array}$ & $\begin{array}{l}0.033^{* * *} \\
(0.010)\end{array}$ & $\begin{array}{l}0.043 * * * \\
(0.012)\end{array}$ & $\begin{array}{l}0.040 * * * \\
(0.013)\end{array}$ & $\begin{array}{l}0.035^{* * *} \\
(0.012)\end{array}$ & $\begin{array}{l}0.039 * * * \\
(0.012)\end{array}$ \\
\hline Paper3 & $\begin{array}{l}0.057 * * * \\
(0.011)\end{array}$ & $\begin{array}{l}0.042 * * * \\
(0.011)\end{array}$ & $\begin{array}{l}0.034 * * * \\
(0.011)\end{array}$ & $\begin{array}{l}0.029 * * * \\
(0.011)\end{array}$ & $\begin{array}{l}0.042 * * * \\
(0.013)\end{array}$ & $\begin{array}{l}0.035^{* *} \\
(0.013)\end{array}$ & $\begin{array}{l}0.027 * * \\
(0.013)\end{array}$ & $\begin{array}{l}0.024 * \\
(0.013)\end{array}$ \\
\hline TV2 & $\begin{array}{l}0.037 * * * \\
(0.011)\end{array}$ & $\begin{array}{l}0.032 * * * \\
(0.011)\end{array}$ & $\begin{array}{l}0.033 * * * \\
(0.011)\end{array}$ & $\begin{array}{l}0.037 * * * \\
(0.011)\end{array}$ & $\begin{array}{l}0.029 * * \\
(0.013)\end{array}$ & $\begin{array}{l}0.024 * \\
(0.014) \\
\end{array}$ & $\begin{array}{l}0.024 * \\
(0.014) \\
\end{array}$ & $\begin{array}{l}0.027 * * \\
(0.014)\end{array}$ \\
\hline TV3 & $\begin{array}{l}-0.014 \\
(0.014)\end{array}$ & $\begin{array}{l}0.008 \\
(0.014) \\
\end{array}$ & $\begin{array}{l}0.009 \\
(0.014) \\
\end{array}$ & $\begin{array}{l}0.025 * \\
(0.013)\end{array}$ & $\begin{array}{l}-0.013 \\
(0.015) \\
\end{array}$ & $\begin{array}{r}-0.003 \\
(0.016) \\
\end{array}$ & $\begin{array}{l}-0.002 \\
(0.015) \\
\end{array}$ & $\begin{array}{l}0.011 \\
(0.015)\end{array}$ \\
\hline White & $\begin{array}{l}0.056 * * * \\
(0.010)\end{array}$ & $\begin{array}{l}0.040 * * * \\
(0.011)\end{array}$ & $\begin{array}{l}0.041 * * * \\
(0.011)\end{array}$ & $\begin{array}{l}0.036^{* * * *} \\
(0.011)\end{array}$ & $\begin{array}{l}0.073 * * * \\
(0.013)\end{array}$ & $\begin{array}{l}0.067 * * * \\
(0.014)\end{array}$ & $\begin{array}{l}0.068 * * * \\
(0.015)\end{array}$ & $\begin{array}{l}0.064 * * * \\
(0.014)\end{array}$ \\
\hline Male & $\begin{array}{l}0.074 * * * \\
(0.009)\end{array}$ & $\begin{array}{l}0.056^{* * * *} \\
(0.010)\end{array}$ & $\begin{array}{l}0.055^{* * *} \\
(0.009)\end{array}$ & $\begin{array}{l}0.032 * * * \\
(0.009)\end{array}$ & $\begin{array}{l}0.100^{* * * *} \\
(0.013)\end{array}$ & $\begin{array}{l}0.088 * * * \\
(0.013)\end{array}$ & $\begin{array}{l}0.087 * * * \\
(0.013)\end{array}$ & $\begin{array}{l}0.069 * * * \\
(0.013)\end{array}$ \\
\hline Sep 11 & $\begin{array}{l}-0.187 * * * \\
(0.028)\end{array}$ & $\begin{array}{l}-0.187 * * * \\
(0.028)\end{array}$ & $\begin{array}{l}0.044 * * \\
(0.022)\end{array}$ & $\begin{array}{l}0.044 * \\
(0.023)\end{array}$ & $\begin{array}{l}-0.193 * * * \\
(0.040)\end{array}$ & $\begin{array}{l}-0.193 * * * \\
(0.040)\end{array}$ & $\begin{array}{l}-0.005 \\
(0.031)\end{array}$ & $\begin{array}{l}-0.005 \\
(0.032)\end{array}$ \\
\hline $\begin{array}{l}\text { Debt } \\
\text { Burden } 2\end{array}$ & & $\begin{array}{l}-0.012 \\
(0.008)\end{array}$ & $\begin{array}{l}-0.014 * \\
(0.008)\end{array}$ & $\begin{array}{l}0.007 \\
(0.008)\end{array}$ & & $\begin{array}{l}-0.015 \\
(0.011)\end{array}$ & $\begin{array}{l}-0.017 \\
(0.011)\end{array}$ & $\begin{array}{l}-0.000 \\
(0.011)\end{array}$ \\
\hline $\begin{array}{l}\text { Debt } \\
\text { Burden } 3\end{array}$ & & $\begin{array}{l}-0.028 * * * \\
(0.010)\end{array}$ & $\begin{array}{l}-0.028 * * * \\
(0.009)\end{array}$ & $\begin{array}{l}0.031 * * * \\
(0.009)\end{array}$ & & $\begin{array}{l}-0.004 \\
(0.012)\end{array}$ & $\begin{array}{l}-0.004 \\
(0.011)\end{array}$ & $\begin{array}{l}0.042 * * * \\
(0.012)\end{array}$ \\
\hline
\end{tabular}


Table 3 continued

\begin{tabular}{|c|c|c|c|c|c|c|c|c|}
\hline Income 2 & & $\begin{array}{l}0.046 * * * \\
(0.012)\end{array}$ & $\begin{array}{l}0.042 * * * \\
(0.011)\end{array}$ & $\begin{array}{l}0.031 * * * \\
(0.011)\end{array}$ & & $\begin{array}{l}0.021 \\
(0.013)\end{array}$ & $\begin{array}{l}0.016 \\
(0.013)\end{array}$ & $\begin{array}{l}0.008 \\
(0.013)\end{array}$ \\
\hline Income3 & & $\begin{array}{l}0.090 * * * \\
(0.009)\end{array}$ & $\begin{array}{l}0.090 * * * \\
(0.009)\end{array}$ & $\begin{array}{l}0.068 * * * \\
(0.009)\end{array}$ & & $\begin{array}{l}0.056^{* * *} \\
(0.012)\end{array}$ & $\begin{array}{l}0.056 * * * \\
(0.012)\end{array}$ & $\begin{array}{l}0.039 * * * \\
(0.012)\end{array}$ \\
\hline Income4 & & $\begin{array}{l}0.141^{* * *} \\
(0.010)\end{array}$ & $\begin{array}{l}0.148^{* * * *} \\
(0.010)\end{array}$ & $\begin{array}{l}0.114 * * * \\
(0.010)\end{array}$ & & $\begin{array}{l}0.105 * * * \\
(0.013)\end{array}$ & $\begin{array}{l}0.110^{* * * *} \\
(0.012)\end{array}$ & $\begin{array}{l}0.083 * * * \\
(0.012)\end{array}$ \\
\hline $\begin{array}{l}\text { Home- } \\
\text { owner }\end{array}$ & & $\begin{array}{l}-0.005 \\
(0.010) \\
\end{array}$ & $\begin{array}{l}-0.007 \\
(0.010) \\
\end{array}$ & $\begin{array}{l}-0.029 * * * \\
(0.009)\end{array}$ & & $\begin{array}{l}-0.020^{*} \\
(0.012)\end{array}$ & $\begin{array}{l}-0.022 * \\
(0.011)\end{array}$ & $\begin{array}{l}-0.039 * * * \\
(0.011)\end{array}$ \\
\hline Employed & & $\begin{array}{l}0.063 * * * \\
(0.008)\end{array}$ & $\begin{array}{l}0.060 * * * \\
(0.008)\end{array}$ & $\begin{array}{l}0.062 * * * \\
(0.007)\end{array}$ & & $\begin{array}{l}0.031 * * * \\
(0.010)\end{array}$ & $\begin{array}{l}0.028 * * * \\
(0.009)\end{array}$ & $\begin{array}{l}0.030 * * * \\
(0.010)\end{array}$ \\
\hline SFD & & & & $\begin{array}{l}-0.115^{* * *} \\
(0.003)\end{array}$ & & & & $\begin{array}{l}-0.090 * * * \\
(0.004)\end{array}$ \\
\hline Constant & $\begin{array}{l}2.100 * * * \\
(0.027)\end{array}$ & $\begin{array}{l}2.036^{* * *} \\
(0.028)\end{array}$ & $\begin{array}{l}2.164 * * * \\
(0.030)\end{array}$ & $\begin{array}{l}2.484 * * * \\
(0.030)\end{array}$ & $\begin{array}{l}2.002 * * * \\
(0.030)\end{array}$ & $\begin{array}{l}1.970 * * * \\
(0.032)\end{array}$ & $\begin{array}{l}2.095 * * * \\
(0.035)\end{array}$ & $\begin{array}{l}2.345^{* * *} \\
(0.037)\end{array}$ \\
\hline $\begin{array}{l}\text { Time } \\
\text { Dummies }\end{array}$ & NO & NO & YES & YES & NO & NO & YES & YES \\
\hline $\begin{array}{l}\text { Adjusted } \\
\text { R2 }\end{array}$ & 0.081 & 0.107 & 0.153 & 0.192 & 0.053 & 0.070 & 0.101 & 0.115 \\
\hline F-Statistic & 167.04 & 170.31 & 318.62 & 620.95 & 82.70 & 87.30 & 160.01 & 173.69 \\
\hline
\end{tabular}

Notes: All the results displayed are OLS coefficients. Standard errors are robust and clustered for each month. ***, **, * indicates significance, respectively, at $1 \%, 5 \%$ and $10 \%$ level. Time dummies indicate monthly and yearly dummies. Total sample size in all the models is 16771. The omitted categories are those who have completed less than high school, whose age is between 26 and 45, who read no newspaper last week and on average watches no TV per day, and whose credit card debt is in the bottom third of the sample.

In models (3) and (7) we include both month and year dummies to control for seasonal aggregate effects in the economy. All of the previous results still hold even after adding time dummies. Although the coefficients change slightly, their significance and direction of correlation stays the same for all of the coefficients except one. The dummy variable that indicates the terrorists attacks of September 2001 had a negative coefficient without time dummies but this becomes positive for CCI (and insignificant for ICE) after controlling for time fixed effects. This indicates that the effect of the terrorist attacks on consumer confidence only had short term effects and consumers' future expectations were not influenced.

The subjective financial distress. In models (4) and (8) we report the results of adding subjective financial distress (SFD) in our model. Debt burden that was used in the previous models is a proxy for objective financial distress. However we are interested the psychological dimensions of debt stress on consumer confidence, hence we use SFD in the final model. 
SFD is negatively and significantly correlated with both CCI (Model 4) and ICE (Model 8). The coefficient on SFD is higher than in absolute value from all of the other socioeconomic variables. This shows that even after controlling for all the other observable characteristics, subjective debt distress can still have some predictive power for consumer confidence. Furthermore the fact that this correlation is negative indicates that the households who see their debt levels to be problematic are more likely to feel pessimistic about economic conditions.

We also analyze whether the impact of SFD is different among certain objective financial conditions. Previous results show that higher distress leads to lower confidence, However, is the strength of this correlation different for example between low income and high income households, or homeowners and others? We thus add interaction variables and re-estimate Model (4). We interact dummy variables indicating debt burden, income quantile, and employment and homeownership status of the households with overall SFD variable. When we add the interaction variables to the final model one at a time, they turn out to be insignificant and the significance of all the other coefficients remains unaffected ${ }^{[9]}$. Thus the relationship between CCI and SFD is not systematically different among various objective financial conditions which indicates that SFD captures something other than objective conditions.

The events of September 2011 are also of interest for this paper. Those events can be considered as a shock to the aggregate economy. We see in all the models in Table 3 that households have lower consumer confidence after this exogenous shock. However when we interacted Sep11 dummy with SFD, once again we obtain a statistically nonsignificant coefficient. Thus we can conclude that the relationship between stress and confidence was not influenced by this aggregate shock.

The individual components of consumer confidence. Finally, we estimate the relationship between consumer confidence and our independent variables by using ordered logistic regression. In the previous sections we have created a continuous variable that includes five different questions about the consumer attitudes. In order to find out if the independent variables have a different association with individual components of the index, we use each question as a separate dependent variable. Since the individual questions are ordered in nature, we utilize ordered logit model. The SFD variable is still coded as continuous where higher numbers indicate more financial distress. Since the coefficient estimates from ordered logit are not meaningful besides their signs and statistical significance, we present the marginal effects for each variable we are interested in. The partial effects show the impact of the explanatory variables on the individual probabilities for each state of the dependent variable, and the sum of all these probabilities should be zero. In our Table 4 this means that the sum of the marginal effects on each row should be zero for a given dependent variable.

[9] The results are not provided here but are available upon request. 


\begin{tabular}{|c|c|c|c|c|c|c|c|c|c|c|c|c|c|}
\hline \multirow{13}{*}{ 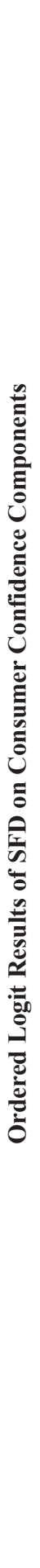 } & \multirow{3}{*}{ 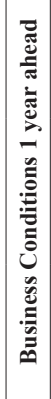 } & 栉 & 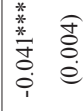 & 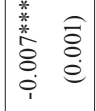 & 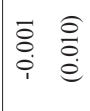 & $\begin{array}{ll}\stackrel{n}{0} & \widehat{\Xi} \\
0 & 0 \\
0\end{array}$ & $\begin{array}{ll}a & \widehat{I} \\
\dot{0} & 0 \\
\dot{0} & 0\end{array}$ & $\begin{array}{ll}\stackrel{*}{*} & \stackrel{0}{0} \\
\stackrel{0}{0} & \stackrel{0}{e}\end{array}$ & 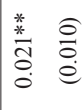 & 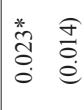 & \begin{tabular}{ll}
$*$ & $\infty$ \\
\multirow{3}{*}{} & 0 \\
0 & 0 \\
0 & $\stackrel{e}{e}$
\end{tabular} & 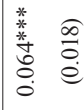 & 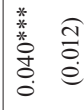 \\
\hline & & 苛 & 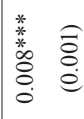 & 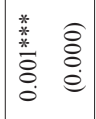 & $\begin{array}{ll}0 & \widehat{\Xi} \\
0 & 0 \\
0 & 0 \\
0 & 0\end{array}$ & 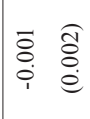 & $\begin{array}{ll}\widetilde{o} & \widehat{\Xi} \\
0 & 0 \\
0 & 0 \\
1 & 0\end{array}$ & 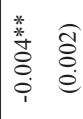 & 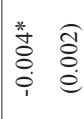 & 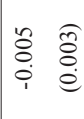 & 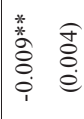 & 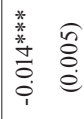 & $\begin{array}{ll}* & \widehat{*} \\
* & 0 \\
o & 0 \\
0 & 0 \\
0 & 0 \\
1 & 0\end{array}$ \\
\hline & & 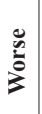 & 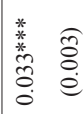 & 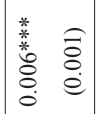 & 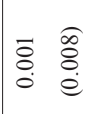 & 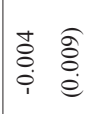 & $\begin{array}{ll}\hat{0} & 0 \\
0 & 0 \\
0 & 0 \\
1 & 0\end{array}$ & 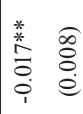 & 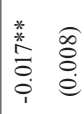 & 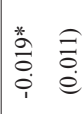 & 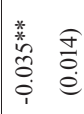 & 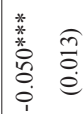 & 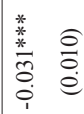 \\
\hline & \multirow{3}{*}{ 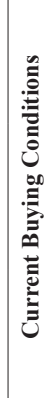 } & 离 & 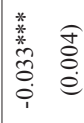 & 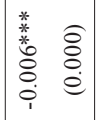 & $\begin{array}{ll}\Delta & \hat{\theta} \\
0 & 0 \\
0 & 0\end{array}$ & $\begin{array}{ll} & \widehat{\Xi} \\
\stackrel{0}{0} & \stackrel{\theta}{e}\end{array}$ & 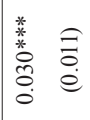 & 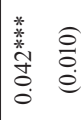 & 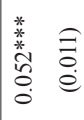 & 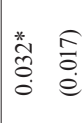 & 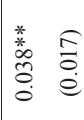 & 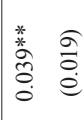 & $\begin{array}{cc}\tilde{c} & \hat{n} \\
\stackrel{0}{0} & \stackrel{0}{0}\end{array}$ \\
\hline & & 营 & 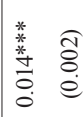 & 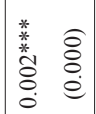 & 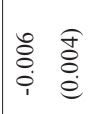 & 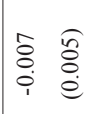 & 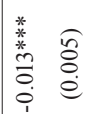 & 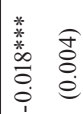 & 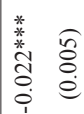 & 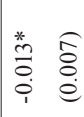 & 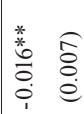 & 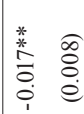 & $\begin{array}{ll}\vec{\Xi} & 0 \\
\vdots & \vdots \\
i & \stackrel{0}{0}\end{array}$ \\
\hline & & $\begin{array}{l}\mathscr{0} \\
\dot{0} \\
\dot{0}\end{array}$ & 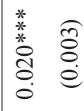 & 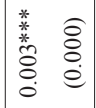 & $\begin{array}{ll}0 & 0 \\
0 & 0 \\
0 & 0 \\
0 & 0 \\
1 & 0\end{array}$ & $\begin{array}{ll}0 & 0 \\
0 & 0 \\
0 & 0 \\
0 & 0 \\
1 & 0\end{array}$ & 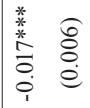 & 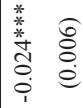 & 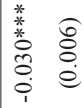 & $\begin{array}{ll}* & \widehat{0} \\
\stackrel{0}{0} & 0 \\
\dot{0} & \stackrel{0}{e}\end{array}$ & 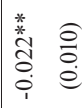 & 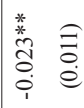 & 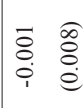 \\
\hline & \multirow{3}{*}{ 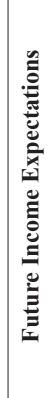 } & 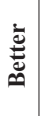 & 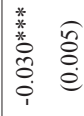 & 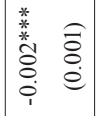 & $\begin{array}{ll}\hat{0} & \hat{0} \\
0 & 0 \\
0 & 0\end{array}$ & 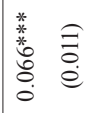 & $\begin{array}{ll}1 & 0 \\
0 & 0 \\
0 & 0 \\
0 & 0\end{array}$ & $\begin{array}{ll} & \widehat{\bar{\theta}} \\
\stackrel{0}{0} & 0\end{array}$ & 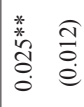 & 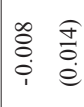 & 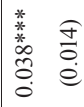 & $\begin{array}{ll}\hat{\sigma} & \infty \\
\stackrel{0}{0} & \stackrel{0}{e} \\
\dot{0} & \end{array}$ & 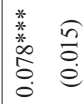 \\
\hline & & 曷 & 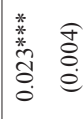 & 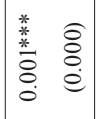 & 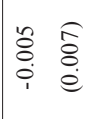 & 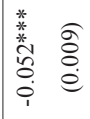 & 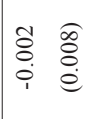 & $\begin{array}{ll}0 & \hat{\sigma} \\
0 & 0 \\
i & 0 \\
i & 0\end{array}$ & 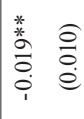 & $\begin{array}{ll}\stackrel{0}{0} \\
\stackrel{0}{0}\end{array}$ & 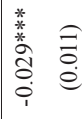 & 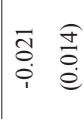 & 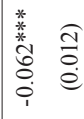 \\
\hline & & $\begin{array}{l}: \\
\dot{0} \\
\dot{0} \\
z\end{array}$ & 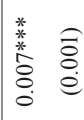 & 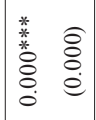 & 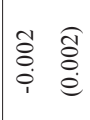 & 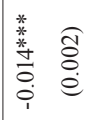 & $\begin{array}{ll}\vec{\delta} & \widehat{\delta} \\
0 & 0 \\
\dot{0} & 0 \\
1 & 0\end{array}$ & $\begin{array}{ll}\bar{\Xi} & \widehat{\hat{\theta}} \\
\dot{0} & 0 \\
i & \stackrel{e}{e}\end{array}$ & $\begin{array}{ll}* & \widehat{\sigma} \\
0 & 0 \\
0 & 0 \\
0 & 0 \\
1 & 0\end{array}$ & 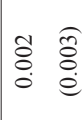 & 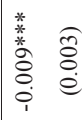 & 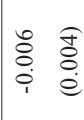 & 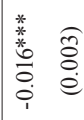 \\
\hline & \multirow{4}{*}{ 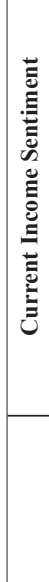 } & 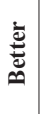 & 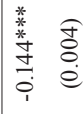 & 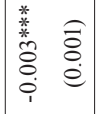 & $\begin{array}{cc}\vec{\Xi} & \widehat{I} \\
\dot{0} & 0 \\
\dot{0} & \stackrel{e}{e}\end{array}$ & $\begin{array}{ll}\infty & \hat{\sigma} \\
\stackrel{0}{0} & \stackrel{0}{\dot{e}}\end{array}$ & 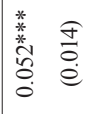 & 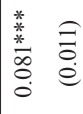 & 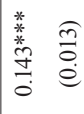 & 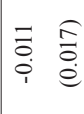 & $\begin{array}{ll}0 & 0 \\
0 & 0 \\
0 & 0 \\
i & 0\end{array}$ & 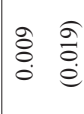 & 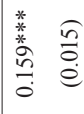 \\
\hline & & 节 & 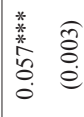 & 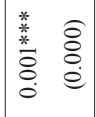 & 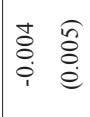 & 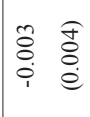 & 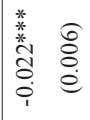 & 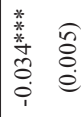 & 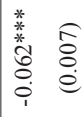 & 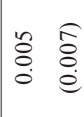 & $\begin{array}{ll}\overline{0} & 0 \\
\dot{0} & \vdots \\
\circ & 0\end{array}$ & $\begin{array}{ll}1 & 0 \\
0 & 0 \\
0 & 0 \\
i & \stackrel{0}{e}\end{array}$ & 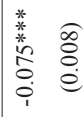 \\
\hline & & $\begin{array}{l}\ddot{0} \\
\dot{0} \\
\dot{0} \\
\dot{0}\end{array}$ & 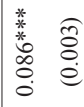 & 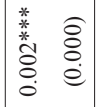 & $\begin{array}{ll}0 & \hat{8} \\
0 & 0 \\
0 & 0 \\
0 & 0\end{array}$ & 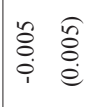 & 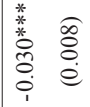 & \begin{tabular}{ll}
$*$ & 0 \\
$*$ & 0 \\
\multirow{2}{*}{} & 0 \\
0 & 0 \\
& 0
\end{tabular} & 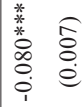 & $\begin{array}{ll}\hat{o} & \hat{0} \\
0 & 0 \\
0 & \stackrel{e}{0}\end{array}$ & 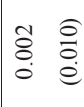 & $\begin{array}{ll}0 & \bar{\Xi} \\
\vdots & 0 \\
\dot{0} & \stackrel{e}{e}\end{array}$ & 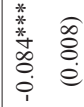 \\
\hline & & & 窝 & 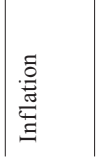 & 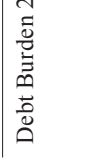 & 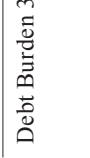 & 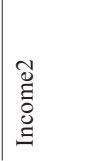 & $\begin{array}{l}\tilde{O} \\
\tilde{\Xi} \\
0 \\
.\end{array}$ & 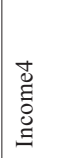 & 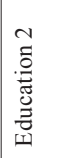 & 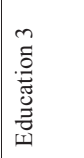 & 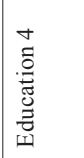 & $\overrightarrow{0}$ \\
\hline
\end{tabular}




\begin{tabular}{|c|c|c|c|c|c|c|c|c|c|c|c|}
\hline 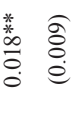 & 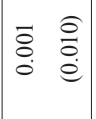 & 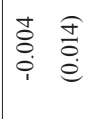 & $\begin{array}{ll}\hat{0} & \widehat{\sigma} \\
0 & 0 \\
\dot{0} & 0 \\
1 & 0\end{array}$ & 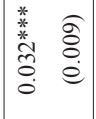 & $\begin{array}{ll}\frac{*}{*} & \widehat{\overrightarrow{0}} \\
\frac{*}{*} & 0 \\
\dot{0} & \dot{e}\end{array}$ & 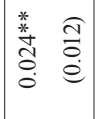 & 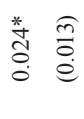 & $\begin{array}{ll}0 & \widehat{a} \\
\stackrel{0}{0} & \stackrel{0}{0}\end{array}$ & $\begin{array}{ll} \pm & \widehat{m} \\
\stackrel{0}{0} & \stackrel{0}{0}\end{array}$ & 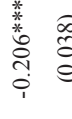 & \\
\hline 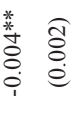 & 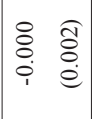 & $\begin{array}{ll}\overrightarrow{0} & \tilde{8} \\
0 & 0 \\
0 & \dot{e}\end{array}$ & $\mid \begin{array}{ll}0 & \widehat{0} \\
0 & 0 \\
0 & 0\end{array}$ & 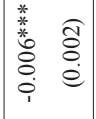 & 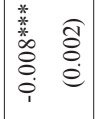 & 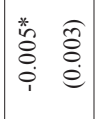 & 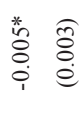 & 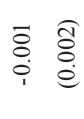 & 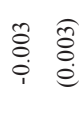 & 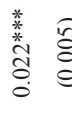 & \\
\hline 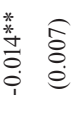 & $\begin{array}{ll}\vec{\delta} & 0 \\
0 & 0 \\
\dot{0} & 0 \\
1 & \dot{e}\end{array}$ & 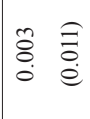 & $\begin{array}{cc}\dot{t} & \widehat{\bar{\sigma}} \\
\dot{0} & 0 \\
0 & \hat{e}\end{array}$ & 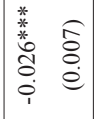 & 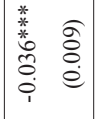 & 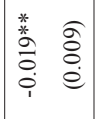 & 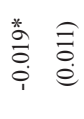 & $\begin{array}{ll}\stackrel{0}{0} \\
\stackrel{0}{0} \\
\dot{0} & \stackrel{0}{0}\end{array}$ & $\begin{array}{ll}\bar{\sigma} & \widehat{\circ} \\
\dot{0} & 0 \\
\dot{e} & \stackrel{e}{e}\end{array}$ & 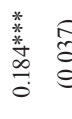 & \\
\hline 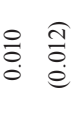 & $\begin{array}{cc}\cong & 0 \\
0 & 0 \\
0 & 0 \\
1 & e\end{array}$ & 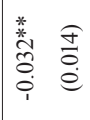 & 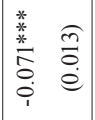 & 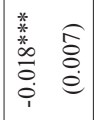 & 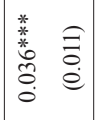 & 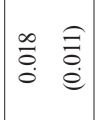 & 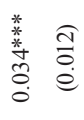 & 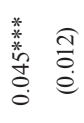 & 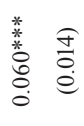 & 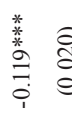 & \\
\hline 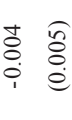 & 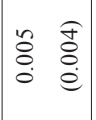 & 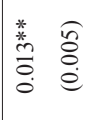 & $\left|\begin{array}{ll}* & \multirow{*}{*}{} \\
* & 0 \\
0 & 0 \\
0 & 0 \\
0 & 0 \\
0 & 0\end{array}\right|$ & 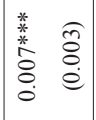 & 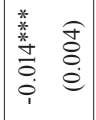 & 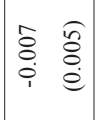 & 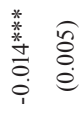 & 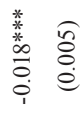 & 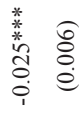 & 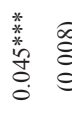 & \\
\hline 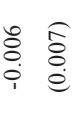 & $\begin{array}{ll}1 & 0 \\
0 & 0 \\
0 & 0 \\
0 & 0\end{array}$ & $\begin{array}{ll}* & 0 \\
* & 0 \\
0 & 0 \\
0 & 0 \\
0 & 0\end{array}$ & 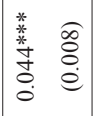 & 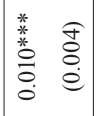 & 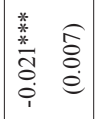 & $\begin{array}{ll}0 & 0 \\
0 & 0 \\
0 & 0 \\
i & 0 \\
1 & 0\end{array}$ & 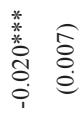 & 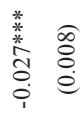 & 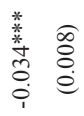 & 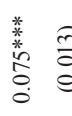 & \\
\hline 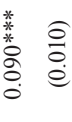 & 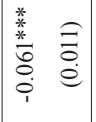 & 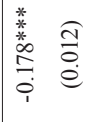 & 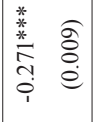 & 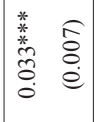 & 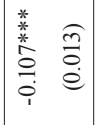 & $\begin{array}{ll}\vec{\Xi} & \widehat{m} \\
\dot{0} & \dot{e} \\
0 & 0\end{array}$ & 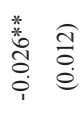 & 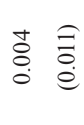 & 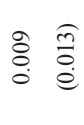 & 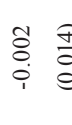 & \\
\hline 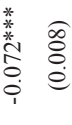 & 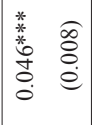 & 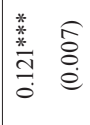 & 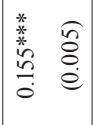 & $\mid \begin{array}{ll}* & 0 \\
* & 0 \\
* & 0 \\
0 & 0 \\
0 & 0 \\
i & 0\end{array}$ & 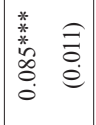 & $\mid \begin{array}{ll}\overrightarrow{0} & 0 \\
0 & 0 \\
0 & 0 \\
1 & 0\end{array}$ & 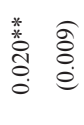 & $\begin{array}{ll}m & \widehat{o} \\
\stackrel{0}{0} & 0 \\
\dot{i} & \stackrel{0}{0}\end{array}$ & $\begin{array}{ll}\hat{o} & \varrho \\
0 & 0 \\
i & 0\end{array}$ & $\vec{\circ}$ & \\
\hline 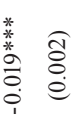 & 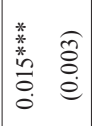 & $\begin{array}{ll}* & 0 \\
* & 0 \\
\infty & 0 \\
0 & 0 \\
0 & 0 \\
0 & 0\end{array}$ & 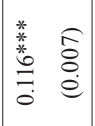 & $\begin{array}{ll}* & \\
* & \widehat{\sigma} \\
* & 0 \\
0 & 0 \\
0 & 0 \\
0 & 0 \\
1 & 0\end{array}$ & 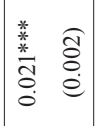 & $\begin{array}{cc}0 & \widehat{0} \\
0 & \delta \\
\dot{0} & 0 \\
1 & 0\end{array}$ & 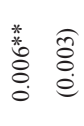 & $\begin{array}{ll}\bar{\partial} & \widehat{o} \\
\dot{0} & 0 \\
\dot{i}\end{array}$ & 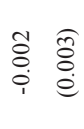 & $\begin{array}{ll}8 & 0 \\
0 & 0 \\
0 & 0\end{array}$ & \\
\hline 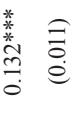 & 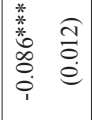 & 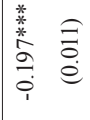 & 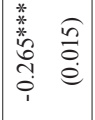 & 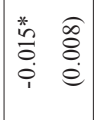 & 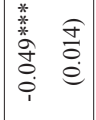 & 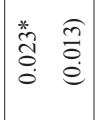 & 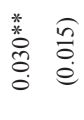 & 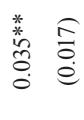 & 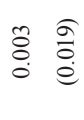 & 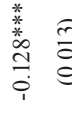 & \\
\hline 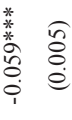 & 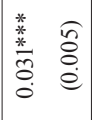 & 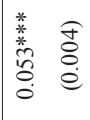 & 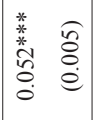 & 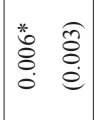 & 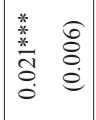 & 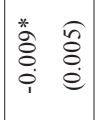 & 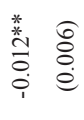 & 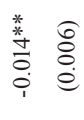 & $\begin{array}{ll}\bar{\partial} & \widehat{o} \\
0 & 0 \\
i & 0 \\
\dot{e}\end{array}$ & 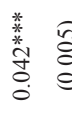 & \\
\hline 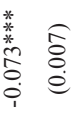 & 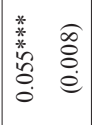 & 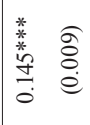 & 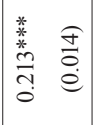 & 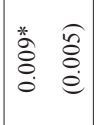 & 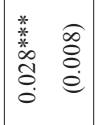 & 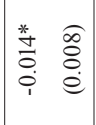 & 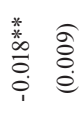 & 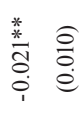 & 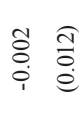 & 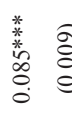 & \\
\hline 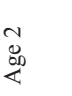 & $\begin{array}{l}+ \\
0 \\
\dot{8} \\
\ll\end{array}$ & $\begin{array}{l}n \\
0 \\
0 \\
\&\end{array}$ & $\begin{array}{l}0 \\
\dot{0} \\
\stackrel{8}{<}\end{array}$ & $\frac{0}{\frac{\pi}{\sigma}}$ & $\stackrel{\frac{0}{3}}{3}$ & 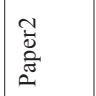 & 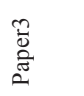 & $\stackrel{\mathcal{Z}}{\mathcal{Z}}$ & $\stackrel{m}{R}$ & $\begin{array}{l}= \\
\text { ेे } \\
\text { ñ }\end{array}$ & \\
\hline
\end{tabular}


Socioeconomic factors and components of CCI. When we look at the individual components of CCI, we have some varying results. For example, education seems to have no or modest correlation with current sentiment and future sentiment, but still has positive correlation with the other two components of the index. Higher educated individuals are $3-4 \%$ more likely to have optimistic expectations about current buying conditions compared to the lowest education group. Age on the other hand is negatively correlated with confidence. For example the people in the oldest age category (more than 65 ) are $26.5 \%$ and $27.1 \%$ less likely to have, respectively, an optimistic current income sentiment and optimistic future income expectations than 26-45 year olds. Males and whites are also found to be less optimistic than their counterparts.

Objective financial conditions also have some varying correlation with confidence. Those in the higher income categories are more likely to be optimistic about current income and buying conditions than those who are in the lowest income quantile; however there seems to be no significant difference between these groups when it comes to future income expectations. Debt burden on the other hand is modestly correlated with future income expectations but not related at all to the other four components of CCI.

SFD and components of CCI. Finally SFD is found to be negatively correlated with all of the four components of CCI. A one-point increase in SFD lowers the probability of reporting optimistic current income sentiment and future income expectations by, respectively, $14.4 \%$ and $3 \%$. Considering the fact that the range of SFD is $1-5$, a onepoint increase means going from "quite a bit" of stress to a "great deal" of stress, or from "no stress at all" to "not very much" stress. Thus these numbers indicate that SFD is a strong correlate of all of the components of consumer confidence.

Other robustness checks. For a robustness check of our results we also estimate the above models by treating SFD variable as discrete. We create dummy variables that correspond to each category of financial distress variables. The results for four of the consumer confidence questions are presented in Appendix Tables (1) and (2). The results confirm previous findings that higher distress is correlated with lower confidence. However the results also show that the effect on probabilities is not constant. For example, the respondents who report "a great deal of stress" about their current debt levels are 28.6\% more likely to report unfavorable changes in their income levels, and $30.9 \%$ less likely to report favorable changes than those who say they worry only "some of the time." On the other extreme, those who worry "not at all" about their debt levels are 5.6\% less likely to report unfavorable changes, and around $10 \%$ more likely to report favorable income changes than the omitted category, "some of the time." These results indicate a strong relationship between confidence and distress measured by "how stressed the respondent is," but the direction of causality is uncertain. Similar results are obtained in the next table for respondent's "concern about ability to be able to never pay off these debts?"[10]

${ }^{[10]}$ This exercise is repeated for all the SFD questions and confidence components separately. Due to page limitations, we are not presenting these results here but they are available upon request. 


\section{Discussion}

We find that financial distress of the surveyed households is associated with consumer confidence, even in the presence of other household-specific economic variables. Under the "information view" described earlier, confidence is merely a prediction of the households' future income that should be captured by their current wealth, debt obligations, and expected real interest rates. Barsky and Sims (2012) use the consumers' self-reported inflation expectations to construct the expected real interest rate variable. We also control for inflation expectations along with other objective financial variables. However, the significance of financial distress despite the presence of all these objective variables in our models cannot be explained by this view.

The relationship between SFD and CCI is not homogeneous among different objective financial conditions. The coefficients of interaction variables between objective variables and SFD are insignificant in our models. If CCI only contained information about objective variables, then the relationship between debt stress and CCI should be stronger for those respondents who are in a financially better situation such as higher income and lower debt burden. However our results contradict this hypothesis.

It is also interesting that the coefficient on the September 11 dummy is significant in all of our models. The terrorist attacks in 2001 can be characterized as a noneconomic event, just as Blanchard (1993) characterized the Iraqi invasion of Kuwait in 1990. The Michigan ICS dropped substantially after both of these events. In fact, the component of ICS that shows future sentiment has dropped much faster than the current sentiment. It is difficult to explain such changes using the information view model, since these events are not associated with changes in future technology and productivity. In fact, the aggregate index returned to its pre-event levels within six months after these events. Another explanation could be that consumers are using something other than information about future economic activity, perhaps animal spirits, in forming their confidence.

We must note that we do not claim a causal relation between the psychological variables used in the paper and the components of the consumer confidence index. As with most of the economic applications, the causality is very difficult to inspect with cross-section data. A possible identification of causality can be achieved by observing the same individuals every month for a year and obtaining information on their confidence and subjective financial distress levels. Not only could this capture the changes in behavior of the individuals, but also it could control for person specific unobserved variables. Another strategy could be to look at the consumption patterns of individuals controlling for confidence and subjective distress measures. If in such a case SFD is found to be correlated to household spending, then the importance of such psychological variables in modeling consumer behavior will be more justified. At this stage, we do not claim that we are able to capture all the potential economic factors that enter into consumer decisions on economic sentiment. Nevertheless, despite these caveats we believe we've shown that certain non-economic variables (which we call subjective financial distress) are highly correlated with traditionally used consumer confidence measures. 


\section{Conclusion}

In this paper we analyze the socioeconomic and psychological correlates of various components of the consumer confidence index in the United States for the period 19982002, using micro level data. Our contribution to the literature is twofold. First, to the best of our knowledge, there is no other study that uses household-level data to identify socioeconomic and demographic factors that are associated with consumer confidence. Furthermore, we introduce a new variable that captures an important psychological state among consumers that might influence their confidence. We are able to use a new and novel data set that has all of this information.

We find that different socioeconomic variables are correlated with the formation of consumer confidence. Some of these variables are home ownership, employment status, income, and the age, gender, and race of the respondents. Objective debt burden of households, measured as the ratio of credit card debt to total household income, is also found to be a significant correlate of future income sentiment, but the results are not robust to different distress questions. Media exposure, measured by number of newspapers read in a week, is found to be correlated with confidence about current financial conditions but not to confidence in future financial conditions.

The significance of demographic variables should be of interest to the readers. Macroeconomic theories of consumer expectations usually assume homogeneity among the agents in the economy. Our results, however, show that consumer confidence is associated with an agent's income, race, age, and even gender. These results imply that there are important differences between various demographic groups in terms of how they perceive economic conditions. These results are in line with previous findings, and should be taken into account by empirical researchers who are trying to incorporate consumer confidence into their forecasting models (Ekici and Dunn, 2010).

Finally, different types of subjective financial distress measures are also associated with confidence in individual components of a consumer confidence index. Consumers with higher levels of distress, measured by the responses given by the consumers themselves, are more likely to have pessimistic attitudes about their own and aggregate economic conditions. This association is very significant, even in the presence of all the other economic variables described earlier. This result confirms that there are noneconomic factors that are included in the formation of consumer confidence. Although we are not able to conclude that financial distress causes consumer confidence, we believe the psychological factors could potentially play an important role in the formation of consumer confidence, but more research is needed to establish the proper link.

Even though the consumer confidence index is widely utilized by the policy makers, some researchers have indicated their hesitation about using this information to forecast economic behavior such as consumption. The results presented here provide important evidence for the existence of non-economic factors, maybe animal spirits, in the formation of consumer confidence. Whether these factors are important for other economic activities of the consumers is another question that should be the focus of future research. 


\section{References}

Acemoğlu, D. and Scott, A. (1994). "Consumer Confidence and Rational Expectations: Are Agents' Beliefs Consistent with the Theory?" The Economic Journal, 104(422): 1-19.

Alsem, K.J., Brakman, S., Hoogduin, L., and Kuper, G. (2008). "The Impact of Newspapers on Consumer Confidence: Does Spin Bias Exist?” Applied Economics, 40: 531-539.

Barsky, R.B. and Sims, E.R. (2012). "Information, Animal Spirits, and the Meaning of Innovations in Consumer Confidence," American Economic Review, 102: 1343-1377.

Beaudry, P. and Portier, F. (2006). "Stock Prices, News and Economic Fluctuations," American Economic Review, 96: 293-1307.

Blanchard, O. (1993). "Consumption and the Recession of 1990-1991," American Economic Review, 83: 270-279.

Bram, J. and Ludvigson, S. (1997). "Does Consumer Sentiment Forecast Household Expenditure? A Sentiment Index Horse Race,” FRB of New York Research Paper, No. 9708.

Brown, S., Taylor, K., and Wheatley Price, S. (2005). "Debt and Distress: Evaluating the Psychological Cost of Credit," Journal of Economic Psychology, 26(5): 642-663.

Carroll, C.D. (2007). "The Epidemiology of Macroeconomics Expectations," in L. Blume and S. Durlauf, (eds.), The Economy as an Evolving Complex System III: 5-29. Oxford, England: Oxford University Press.

Carroll, C.D., Fuhrer, J.C., and Wilcox, D.W. (1994). "Does Consumer Sentiment Forecast Household Spending? If So, Why?" American Economic Review, 84: 1397-1408.

Casey, G.P. and Owen, A. L. (2013). "Good News, Bad News, and Consumer Confidence," Social Science Quarterly, 94 (1): 292-315.

de Mendonca, H.F. (2009). "Brazil: How Macroeconomic Variables Affect Consumer Confidence," Cepal Review, 99: 81-94.

Del Rio, A. and Young, G. (2008). "The Impact of Secured Debt on Financial Pressure Among British Households," Applied Financial Economics, 18: 1209-1220.

Drentea, P. (2000). "Debt and Anxiety," Journal of Health and Social Behavior, 41: 437-450.

Drentea, P. and Lavrakas, P.J. (2000). "Over the Limit: the Association among Health, Race and Debt," Social Science and Medicine, 50: 517-529.

Dunn, L., Ekici, T., Lavrakas, P., and Stec, J. (2006). “An Index to Track Credit Card Debt and Predict Consumption," Unpublished manuscript, Department of Economics, Ohio State University, Columbus, Ohio.

Dunn, L.and Mirzaie, I. (2006). "Turns in Consumer Confidence: An Information Advantage Linked to Manufacturing," Economic Inquiry, 44: 343-351.

------, (2012). "Determinants of Consumer Debt Stress: Differences by Debt Type and Gender," Unpublished manuscript, Department of Economics, Ohio State University, Columbus, Ohio.

Ekici, T. (2006). "Do Inflation Expectations and Consumer Confidence Matter for Credit Card Borrowing: Evidence from Micro Data," Unpublished manuscript, Department of Economics, Ohio State University, Columbus, Ohio.

Ekici, T. and Dunn, L. (2010). "Credit Card Debt and Consumption: Evidence from household-level data," Applied Economics, 42: 455-462. 
Eppright, D.R., Arguea, N.M., and Huth, W.L. (1998). “Aggregate Consumer Expectations Indexes as Indicators of Future Consumption Expenditures," Journal of Economic Psychology, 192: 215-35.

Goh, K.L. (2003). "Does Consumer Confidence Forecast Consumption Expenditure in New Zealand?" New Zealand Treasury Working Paper, No: 03/22.

Golinelli, R. and Parigi, G. (2003). "What is This Thing Called Confidence? A Comparative Analysis of Consumer Confidence Indices in Eight Major Countries," Temi di Discussione no. 484.

Hall, R.E. (1993). "Macro Theory and the Recession of 1990-1991," American Economic Review, 83: $275-279$.

Hollanders, D. and Vliegenthart, R. (2011) "The Influence of Negative Newspaper Coverage on Consumer Confidence: The Dutch Case," Journal of Economic Psychology, 32: 367-373.

Howrey, P.E. (2001). "The Predictive Power of the Index of Consumer Sentiment," Brookings Papers on Economic Activity, 2001: 175-207.

Jansen, W.J. and Nahuis, N.J. (2003) "The Stock Market and Consumer Confidence: European Evidence," Economics Letters, 79: 89-98.

Katona, G. (1951). Psychological Analysis of Economic Behavior. New York: McGraw-Hill (reprinted 1977).

------, (1975). Psychological Economics. Amsterdam: Elsevier.

Keese, M. (2012) "Who Feels Constrained by High Debt Burdens? Subjective vs Objective Measures of Household Debt," Journal of Economic Psychology, 33: 125-141.

Kim, J., Sorhaindo, B., and Garman, E.T. (2006). "Relationship Between Financial Stress and Workplace Absenteeism of Credit Counseling Clients," Journal of Family Economics Issues, 27: 458-478.

Kwan, A.C.C. and Cotsomitis, J.A. (2006). "The Usefulness of Consumer Confidence in Forecasting Household Spending in Canada: A National and Regional Analysis," Economic Inquiry 44(1): 185-197.

Lenton, P., and Mosley, P. (2008). "Debt and health," University of Sheffield, Department of Economics, Working Paper \#2008004.

Lopez, H.B. and Durre, A. (2003). "The Determinants of Consumer Confidence: the Case of United States and Belgium," CORE DP 2003/53.

Ludvigson, S.C. (2004). "Consumer Confidence and Consumer Spending," Journal of Economic Perspectives, 18(2): 29-50.

Malgarini, M. and Margani, P. (2007) "Psychology, Consumer Sentiment and Household Expenditures," Applied Economics, 39: 1719-1729.

Ramos, X. and Schluter, C. (2006). "Subjective Income Expectations and Income Risk," IZA Discussion Paper No: 1950.

Souleles, N.S. (2004). "Expectations, Heterogeneous Forecast Errors, and Consumption: Micro Evidence from the Michigan Consumer Sentiment Surveys," Journal of Money, Credit, and Banking, 36(1), 39-72.

Stewart, M. (2005). "A Comparison of Semiparametric Estimators for Ordered Response Model," Computational Statistics and Data Analysis, 49, 555-73.

Throop, A.W. (1992). "Consumer Sentiment: Its Causes and Effects," Economic Review of the Federal Reserve Bank of San Francisco, (1): 35-59. 


\section{APPENDIX}

Figure A1.

Comparison of Ohio Consumer Confidence Index (OCCI) with the National Index (ICS)

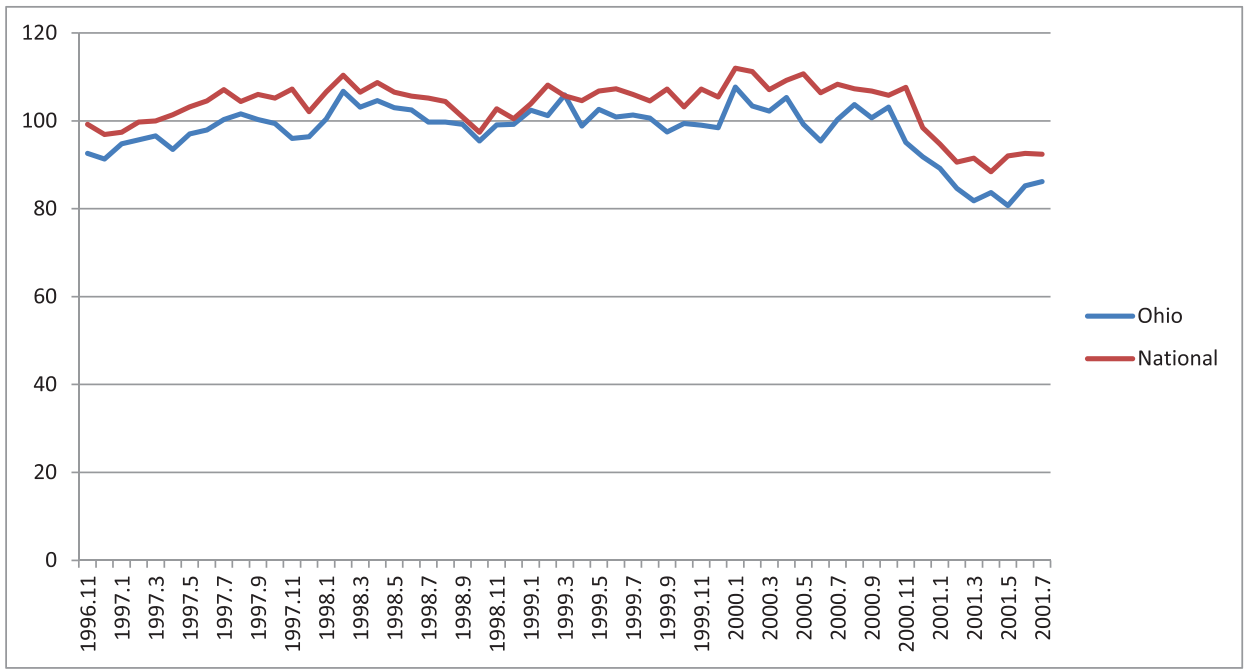




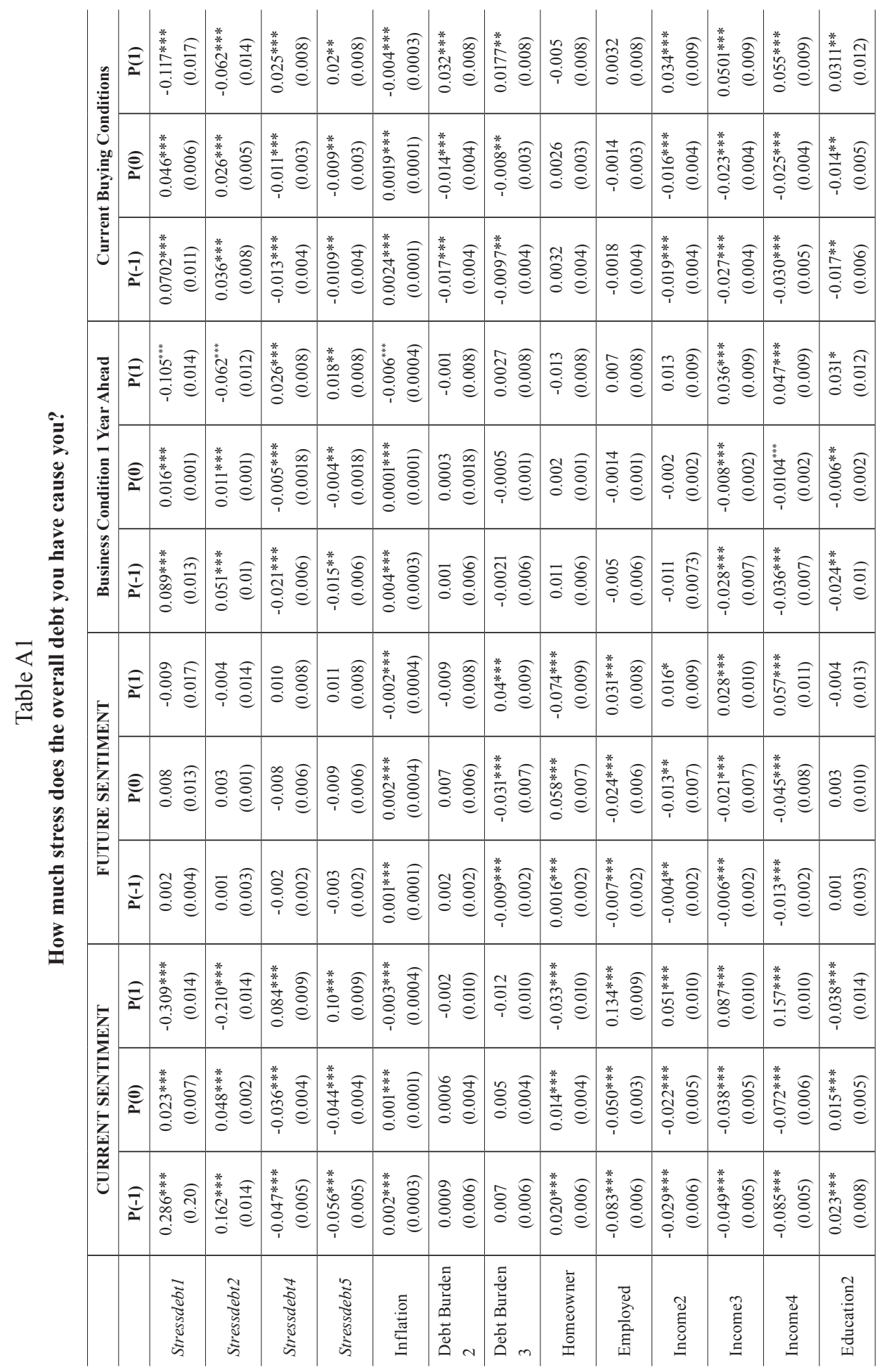




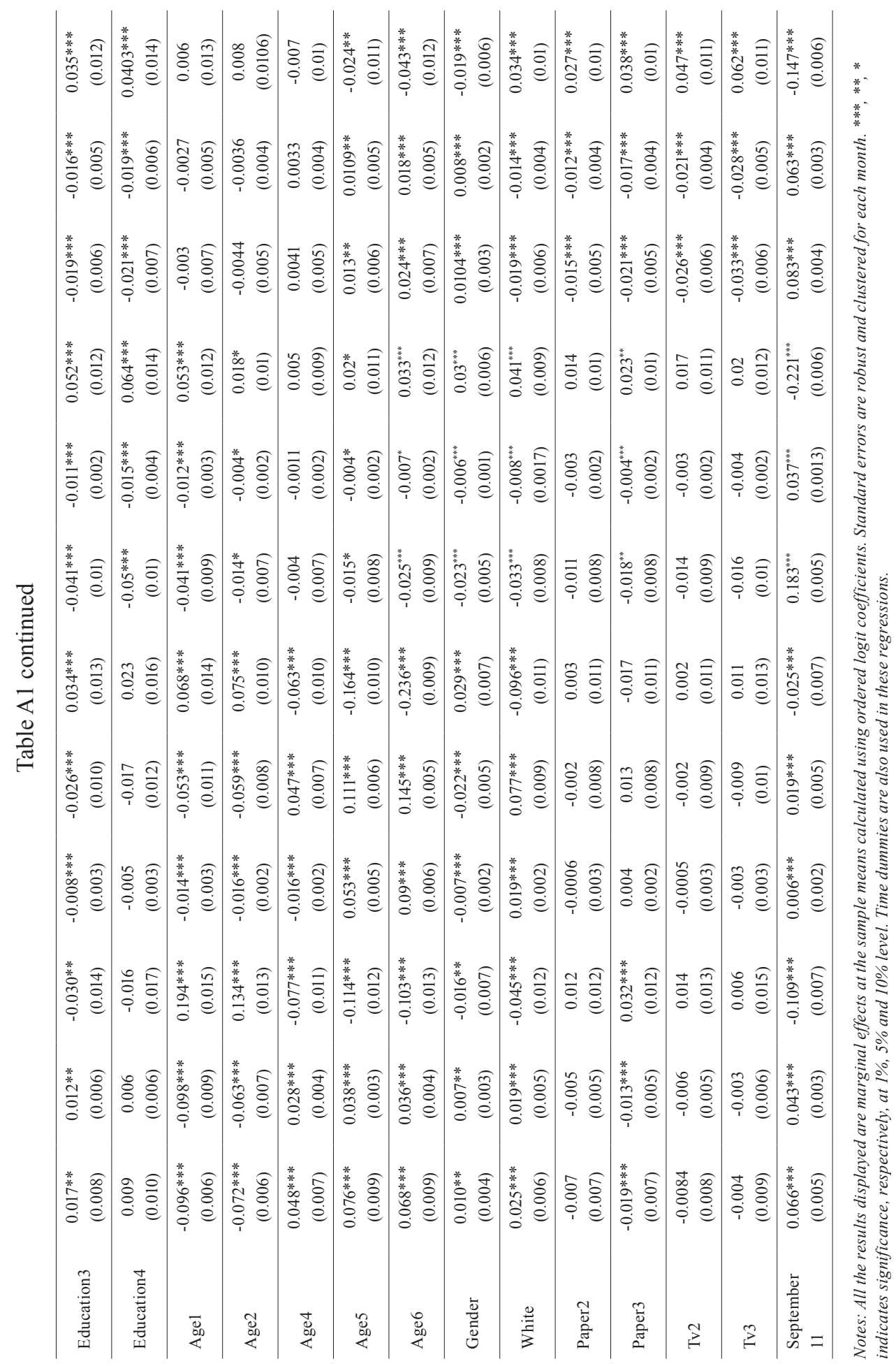




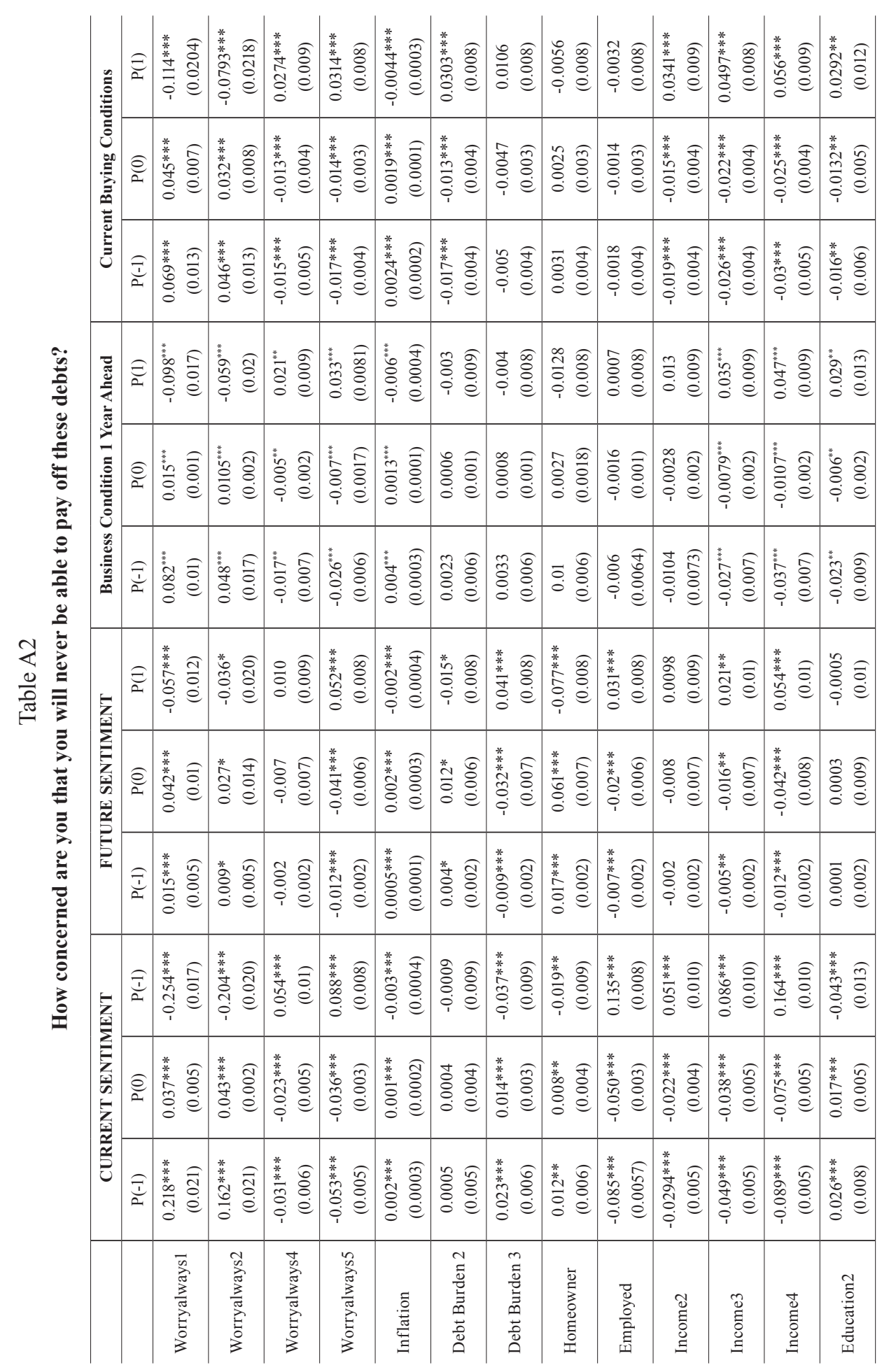




\begin{tabular}{|c|c|c|c|c|c|c|c|c|c|c|c|c|c|}
\hline 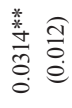 & 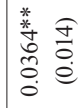 & 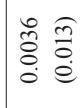 & 苍 $\widehat{\sigma}$ & 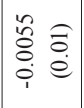 & $\begin{array}{l}\stackrel{0}{\overline{0}} \\
\stackrel{0}{0} \\
\dot{i}\end{array}$ & 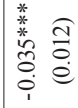 & $\begin{array}{ll}\frac{*}{*} & 0 \\
0 & \vdots \\
0 & 0 \\
0 & 0 \\
1 & 0\end{array}$ & 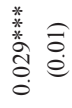 & 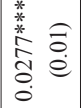 & 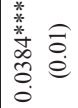 & 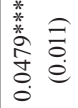 & 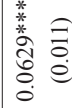 & 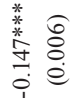 \\
\hline 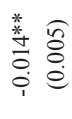 & 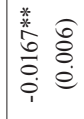 & $\begin{array}{ll} & 0 \\
\stackrel{0}{0} & 0 \\
\dot{0} & 0 \\
& 0\end{array}$ & 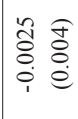 & 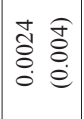 & 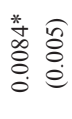 & 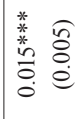 & 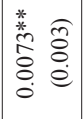 & 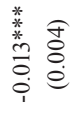 & 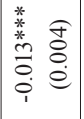 & 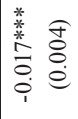 & 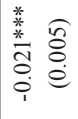 & 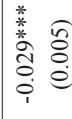 & 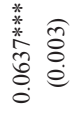 \\
\hline 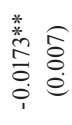 & 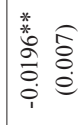 & 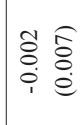 & 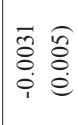 & $\mid \begin{array}{ll}0 & \tilde{o} \\
0 & 0 \\
0 & 0 \\
\dot{\theta}\end{array}$ & 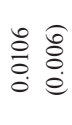 & 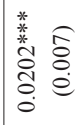 & 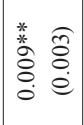 & 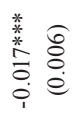 & 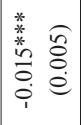 & 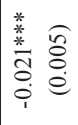 & 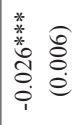 & 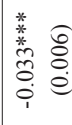 & 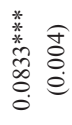 \\
\hline 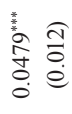 & $\begin{array}{ll}\frac{1}{4} & \frac{n}{0} \\
\stackrel{0}{0} & \stackrel{0}{0}\end{array}$ & 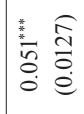 & $\stackrel{0}{\circ} \stackrel{0}{\circ}$ & $\mid \begin{array}{ll}0 & \hat{a} \\
0 & 0 \\
0 & 0 \\
0 & 0\end{array}$ & 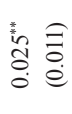 & 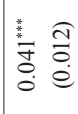 & $\begin{array}{ll} & 0 \\
& \vdots \\
\tilde{c} & \vdots \\
0 & 0 \\
0 & 0\end{array}$ & 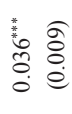 & $\stackrel{n}{\stackrel{0}{a}}$ & 莣 & 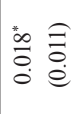 & 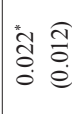 & 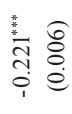 \\
\hline 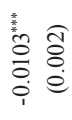 & 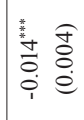 & 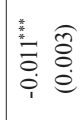 & 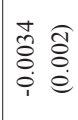 & $\mid \begin{array}{ll}\hat{\vec{\theta}} & \widehat{\sigma} \\
\dot{0} \\
\dot{i} & \dot{e} \\
1 & \end{array}$ & 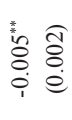 & 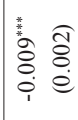 & 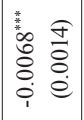 & 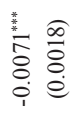 & $\mid \begin{array}{cc}\tilde{c} & \widehat{\Xi} \\
0 & 0 \\
0 & 0 \\
i & 0\end{array}$ & 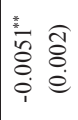 & 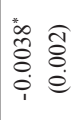 & $\begin{array}{ll}\hat{n} & \widehat{0} \\
0 & 0 \\
0 & 0 \\
1 & 0\end{array}$ & 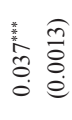 \\
\hline $\begin{array}{l}t_{0}^{\infty} \\
\overbrace{0}^{\infty} \\
\dot{0}\end{array}$ & 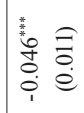 & 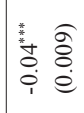 & 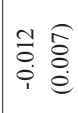 & 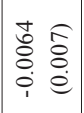 & 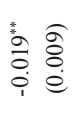 & 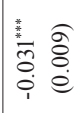 & $\begin{array}{ll}n & 0 \\
h & 0 \\
0 & 0 \\
0 & 0 \\
i & e\end{array}$ & 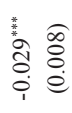 & $\begin{array}{ll}1 & \widehat{o} \\
0 & 0 \\
0 & 0 \\
1 & 0\end{array}$ & $\begin{array}{ll}* & 0 \\
0 & 0 \\
0 & 0 \\
0 & 0 \\
1 & 0\end{array}$ & 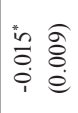 & 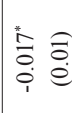 & 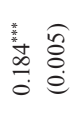 \\
\hline 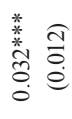 & $\begin{array}{ll}\vec{\delta} & \frac{n}{0} \\
0 & \stackrel{0}{0}\end{array}$ & 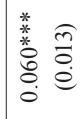 & $\begin{array}{l}\frac{*}{*} \\
\stackrel{*}{*} \\
\stackrel{0}{0} \\
\stackrel{0}{0} \\
\dot{0}\end{array}$ & 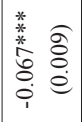 & 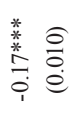 & 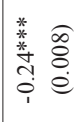 & 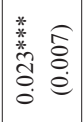 & 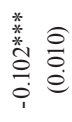 & 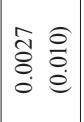 & $\begin{array}{ll}0 & 0 \\
0 & 0 \\
& 0 \\
& 0\end{array}$ & $\begin{array}{ll}\infty & \widehat{\sigma} \\
\stackrel{0}{0} & 0 \\
\dot{0} & \stackrel{0}{e}\end{array}$ & 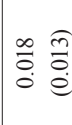 & 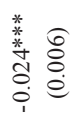 \\
\hline 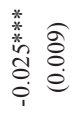 & $\begin{array}{ll}\ddot{0} & \widehat{\Xi} \\
0 & 0 \\
\dot{0} & \stackrel{0}{e}\end{array}$ & 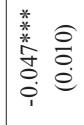 & 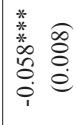 & $\mid \begin{array}{ll}* & 0 \\
* & 0 \\
0 & 0 \\
0 & 0 \\
0 & 0 \\
0 & 0\end{array}$ & 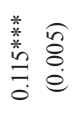 & 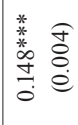 & 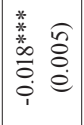 & 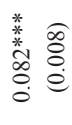 & 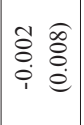 & 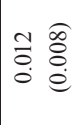 & $\begin{array}{ll}0 & \widehat{o} \\
0 & 0 \\
0 & 0 \\
1 & 0\end{array}$ & $\begin{array}{ll} & 0 \\
0 & 0 \\
0 & 0 \\
1 & 0\end{array}$ & 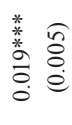 \\
\hline 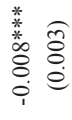 & $\begin{array}{l}n \\
\stackrel{0}{0} \\
\dot{0} \\
i\end{array}$ & 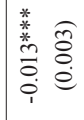 & 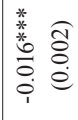 & 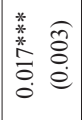 & 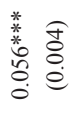 & 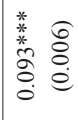 & 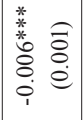 & 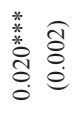 & $\mid \begin{array}{cc}0 & \widehat{0} \\
0 & 0 \\
0 & 0 \\
i & 0\end{array}$ & t) & $\begin{array}{ll}\tau & \widehat{\hat{o}} \\
\delta & 0 \\
i & 0 \\
1 & 0\end{array}$ & $\begin{array}{ll} & \widehat{0} \\
0 & 0 \\
0 & 0 \\
1 & 0\end{array}$ & 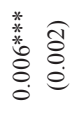 \\
\hline 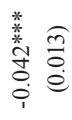 & 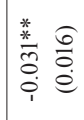 & 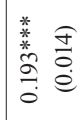 & 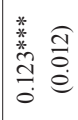 & 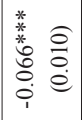 & $\begin{array}{l}\frac{*}{*} \\
\frac{*}{*} \\
\dot{\sigma} \\
\dot{0} \\
\dot{0}\end{array}$ & 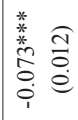 & $\mid \begin{array}{ll}\infty & 0 \\
0 & 0 \\
0 & 0 \\
i & 0 \\
1\end{array}$ & 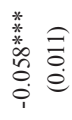 & 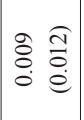 & 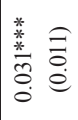 & 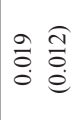 & 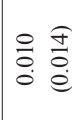 & 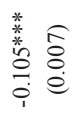 \\
\hline 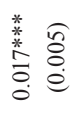 & 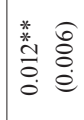 & 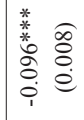 & 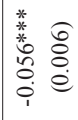 & 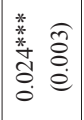 & 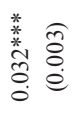 & 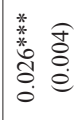 & 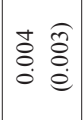 & 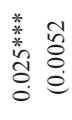 & $\mid \begin{array}{ll}1 & \widehat{a} \\
0 & 0 \\
0 & 0 \\
i & 0\end{array}$ & 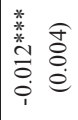 & $\begin{array}{ll}\infty & \widehat{c} \\
0 & 0 \\
0 & 0 \\
i & 0\end{array}$ & $\begin{array}{ll} \pm & 0 \\
0 & 0 \\
0 & 0 \\
1 & 0\end{array}$ & 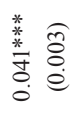 \\
\hline 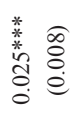 & $\begin{array}{ll}* & \widehat{O} \\
\stackrel{0}{0} & \stackrel{0}{0}\end{array}$ & 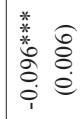 & 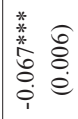 & 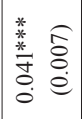 & 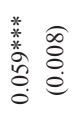 & 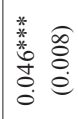 & 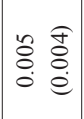 & 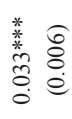 & 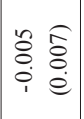 & 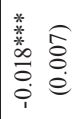 & 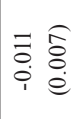 & $\begin{array}{ll}8 & 0 \\
0 & 0 \\
0 & 0 \\
& 0\end{array}$ & 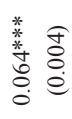 \\
\hline $\begin{array}{l}\tilde{\Xi} \\
\stackrel{0}{\tilde{E}} \\
\tilde{J} \\
\tilde{J}\end{array}$ & 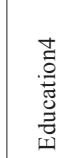 & 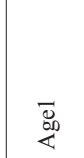 & 总 & $\begin{array}{l}\stackrel{+}{\mathrm{D}} \\
\stackrel{8}{\&}\end{array}$ & 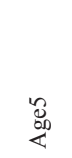 & 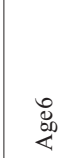 & $\begin{array}{l}\dot{\bar{g}} \\
\overline{0} \\
0 \\
0\end{array}$ & 营 & $\begin{array}{l}\widetilde{\Xi} \\
\text { בे } \\
\text { a. }\end{array}$ & 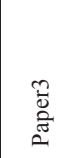 & 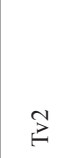 & $\stackrel{B}{E}$ & 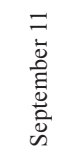 \\
\hline
\end{tabular}

